\title{
Health Functions and Related Molecular Mechanisms of Tea Components: An Update Review
}

\author{
Guo-Yi Tang ${ }^{1,2,+}{ }^{+}$, Xiao Meng ${ }^{1, \dagger}$, Ren-You Gan ${ }^{3,4, *}$, Cai-Ning Zhao ${ }^{1}$, Qing Liu ${ }^{1}$, Yi-Bin Feng ${ }^{2}$, \\ Sha $\mathrm{Li}^{2}$, Xin-Lin Wei ${ }^{3}$, Atanas G. Atanasov ${ }^{5}\left({ }^{(0}\right.$, Harold Corke ${ }^{3}$ and Hua-Bin Li ${ }^{1, *(1)}$ \\ 1 Guangdong Provincial Key Laboratory of Food, Nutrition and Health, Department of Nutrition, School of \\ Public Health, Sun Yat-Sen University, Guangzhou 510080, China; tanggy5@mail2.sysu.edu.cn (G.-Y.T.); \\ mengx7@mail2.sysu.edu.cn (X.M.); zhaocn@mail2.sysu.edu.cn (C.-N.Z.); liuq248@mail2.sysu.edu.cn (Q.L.) \\ 2 School of Chinese Medicine, Li Ka Shing Faculty of Medicine, The University of Hong Kong, No. 10 Sassoon \\ Road, Pokfulam, Hong Kong 999077, China; yfeng@hku.hk (Y.-B.F.); lishaha@hku.hk (S.L.) \\ 3 Department of Food Science \& Technology, School of Agriculture and Biology, Shanghai Jiao Tong University, \\ Shanghai 200240, China; weixinlin@sjtu.edu.cn (X.-L.W.); hcorke@sjtu.edu.cn (H.C.) \\ 4 Institute of Urban Agriculture, Chinese Academy of Agricultural Sciences, Chengdu 610213, China \\ 5 The Institute of Genetics and Animal Breeding, Polish Academy of Sciences, Jastrzębiec, \\ 05-552 Magdalenka, Poland; atanas.atanasov@univie.ac.at \\ * Correspondence: ganrenyou@caas.cn (R.-Y.G.); lihuabin@mail.sysu.edu.cn (H.-B.L.); \\ Tel.: +86-28-80203191 (R.-Y.G.); +86-20-87332391 (H.-B.L.) \\ + The authors contributed equally to this work.
}

Received: 27 October 2019; Accepted: 6 December 2019; Published: 8 December 2019

\begin{abstract}
Tea is widely consumed all over the world. Generally, tea is divided into six categories: White, green, yellow, oolong, black, and dark teas, based on the fermentation degree. Tea contains abundant phytochemicals, such as polyphenols, pigments, polysaccharides, alkaloids, free amino acids, and saponins. However, the bioavailability of tea phytochemicals is relatively low. Thus, some novel technologies like nanotechnology have been developed to improve the bioavailability of tea bioactive components and consequently enhance the bioactivity. So far, many studies have demonstrated that tea shows various health functions, such as antioxidant, anti-inflammatory, immuno-regulatory, anticancer, cardiovascular-protective, anti-diabetic, anti-obesity, and hepato-protective effects. Moreover, it is also considered that drinking tea is safe to humans, since reports about the severe adverse effects of tea consumption are rare. In order to provide a better understanding of tea and its health potential, this review summarizes and discusses recent literature on the bioactive components, bioavailability, health functions, and safety issues of tea, with special attention paid to the related molecular mechanisms of tea health functions.
\end{abstract}

Keywords: tea; Camellia sinensis; phytochemicals; catechins; health benefits; bioavailability; safety

\section{Introduction}

Tea, a beverage prepared from the leaves of Camellia sinensis, originated in ancient China and has become increasingly popular all over the world in recent decades [1]. According to the complex production processes, tea can be classified into six categories, including white, green, yellow, oolong, black, and dark teas. White and green teas are not fermented, yellow tea is just slightly fermented, while oolong, black, and dark teas are more deeply fermented [2-7]. Tea contains various bioactive components, such as polyphenols, pigments, polysaccharides, alkaloids, free amino acids, and saponins [8-13]. In addition, many studies have indicated that tea and its bioactive components possess multiple health functions (as shown in Figure 1), including antioxidation, anti-inflammation, immuno-regulation, anticancer, cardiovascular-protection, 
anti-diabetes, anti-obesity, and hepato-protection [14-19]. Moreover, several technologies, including recently developed nanotechnology, have been adopted to improve the bioavailability of tea polyphenols [20-24]. Furthermore, the adverse effects of tea were seldom observed [25-29]. Thus, the combination of health functions and safety of tea supports its consumption for people with the potential to prevent and manage certain chronic diseases, such as obesity and cancer.

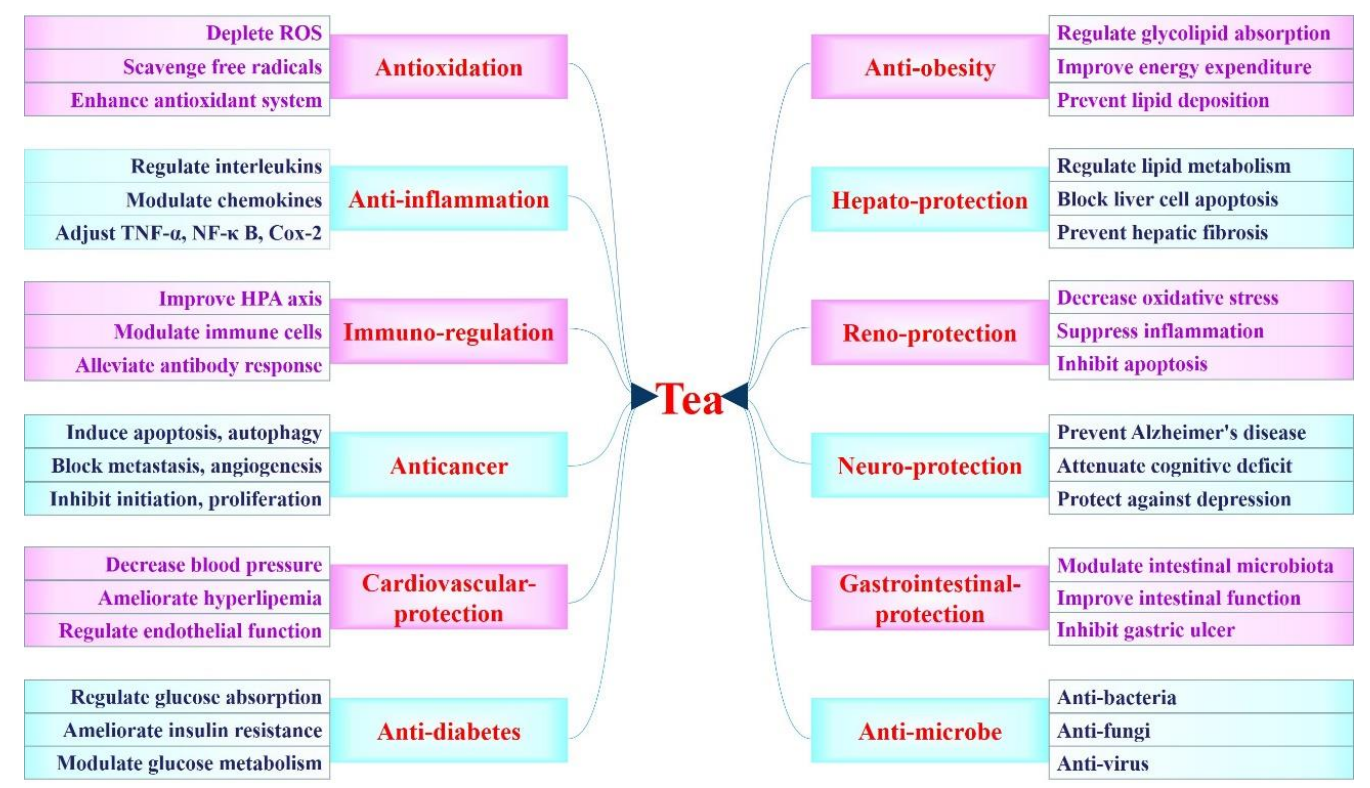

Figure 1. The main health functions of tea.

In order to provide a comprehensive understanding of tea, in this review, its bioactive components, bioavailability, health functions, and safety are summarized and discussed mainly based on in vitro, in vivo, and clinical studies, with highlighting the molecular mechanisms of health functions. Overall, this review can be helpful for the better utilization of tea as beverages and functional foods to prevent and control certain chronic diseases.

\section{Bioactive Components}

Many bioactive components have been identified in tea and its brewing, including polyphenols, pigments, polysaccharides, alkaloids, free amino acids, and saponins, and the amount of these compounds can be quite different in different categories of tea [8-11].

\subsection{Polyphenols}

White, green and yellow teas contain abundant polyphenols, especially catechins and their derivatives, including catechin, epicatechin (EC), gallocatechin (GC), epigallocatechin (EGC), catechin gallate (CG), epicatechin gallate (ECG), gallocatechin gallate (GCG), and epigallocatechin gallate (EGCG) [12,13,30-32]. In addition, other polyphenols like gallic acid, chlorogenic acid, ellagic acid, galloylquinic acid, kaempferol-3-O-glucoside (kaempferol-3-G) and various flavonoids are also found in tea $[12,13,33-35]$. Polyphenols have been reported to exhibit various health functions in vitro and in vivo [30-35]. Specifically, tea polyphenols are one of the most important natural antioxidants [30]. The antioxidant capacity of tea polyphenols can be influenced by the spatial configuration, and generally positively correlate with the number of hydroxyl groups [32,36].

\subsection{Pigments}

During fermentation, tea catechins are oxidized to theaflavins, thearubigins, and theabrownins, therefore, oolong, black, and dark teas are rich in pigments $[4,37,38]$. The structures of theaflavins, which 
have been identified with 4 isomers, including theaflavin, theaflavin-3-gallate, theaflavin- $3^{\prime}$-gallate, and theaflavin-3,3'-gallate, are simpler than those of thearubigins and theabrownins that are complex mixtures of polyphenols and their polymers $[39,40]$. Tea pigments have also been shown as important bioactive components responsible for health functions of tea, like anti-inflammatory, anticancer, and hepato-protective effects, though their antioxidant activity may be lower when compared with tea catechins $[10,17,41]$.

\subsection{Polysaccharides}

Tea polysaccharides (TPS) is another main bioactive component of tea other than polyphenols [42]. The content of polysaccharides in tea could be increased as the maturity of raw tea leaf increased, quite different from the pattern of tea polyphenols [42]. In addition, TPS have diverse chemical characteristics, in terms of the monomer (mainly glucose, galactose, rhamnose, and arabinose, with little xylose and mannose), acidity (neutral or acidic), solubility (water-soluble or not), and conjugation with proteins, polyphenols, metal ions, selenium, strongly influencing the structure-function relationship [42-47]. For example, the complex of tea polysaccharides with lower content of polyphenols exert higher antioxidant activity than those with higher content of polyphenols, and conjugation with selenium could remarkably increase the antioxidant activity of tea polysaccharides [42,46]. Polysaccharides may contribute to the antioxidant, immuno-regulatory, anticancer, anti-diabetic, and anti-obesity effects of tea brewing and its extracts [44,47-50].

\subsection{Alkaloids}

Tea is one of the most important sources of alkaloids, generally as purine alkaloids (e.g., caffeine, theobromine, and theophylline), which can be transformed into flavo-alkaloids [8,51]. A possible pathway has been proposed to involve deamination, decarboxylation, and spontaneously cyclization of L-theanine, and then attachment of the product to EGCG form the flavo-alkaloids [51]. Caffeine is the most abundant alkaloid in all six categories of tea [8]. The antioxidant, anti-diabetic, and anti-obesity effects of tea alkaloids have been described in some studies [30,48,51].

\subsection{Amino Acids}

Tea brewing and its extract also contain a considerable amount of amino acids [52]. Aspartic acid, glutamic acid, arginine, alanine, tyrosine, and theanine have been reported as the major amino acids in tea, and the amino acid profile can be changed during fermentation $[8,29,52]$. Among them, theanine is a nonproteinic amino acid special to tea [8]. It has been summarized that L-theanine has positive effects on relaxation, cognitive performance, emotional status, sleep quality, cancer, cardiovascular diseases, obesity, and the common cold [8,29].

\subsection{Saponins}

Saponins are another bioactive component in tea brewing and its extract, and usually exhibit antioxidant, immuno-regulatory, anticancer, and cardiovascular-protective effects [11,53-55]. Moreover, tea saponins are generally regarded as safe compounds that have anti-fungal and insecticidal properties and are widely used in the field of agriculture and food industry [56,57].

Phytochemical contents of 6 representative tea samples from six categories are summarized in Table 1. Eight catechins, caffeine, theaflavine, gallic acid, chlorogenic acid, ellagic acid, and kaempferol-3-G are the main chemical compounds in tea [12,13]. In addition, the chemical structures of main phytochemical compounds in tea are shown in Figure 2. 
Table 1. Phytochemical content (mg/g DW) of 6 representative teas from six categories [12].

\begin{tabular}{ccccccc}
\hline \multirow{2}{*}{ Phytochemicals } & $\begin{array}{c}\text { Gongmei } \\
\text { Tea }\end{array}$ & $\begin{array}{c}\text { Dianqing } \\
\text { Tea }\end{array}$ & $\begin{array}{c}\text { Junshan } \\
\text { Yinzhen Tea }\end{array}$ & $\begin{array}{c}\text { Fenghuang } \\
\text { Shuixian Tea }\end{array}$ & $\begin{array}{c}\text { Yichang } \\
\text { Congou Tea }\end{array}$ & $\begin{array}{c}\text { Fuzhuan } \\
\text { Brick Tea }\end{array}$ \\
\cline { 2 - 7 } & White Tea & Green Tea & Yellow Tea & Oolong Tea & Black Tea & Dark Tea \\
\hline Catechin & ND & 1.37 & 1.32 & ND & ND & 4.93 \\
EC & ND & 6.20 & 5.97 & 1.58 & 0.74 & 10.36 \\
GC & ND & 2.74 & 1.86 & 2.51 & ND & 5.54 \\
EGC & 8.42 & 13.66 & 13.09 & 31.25 & ND & 23.43 \\
CG & ND & 0.35 & ND & ND & ND & ND \\
ECG & 3.14 & 30.49 & 35.40 & 8.44 & 3.51 & 10.88 \\
GCG & ND & 1.45 & ND & ND & 0.51 & 0.93 \\
EGCG & 6.01 & 50.78 & 59.35 & 36.70 & 3.80 & 10.89 \\
Galli acid & 2.18 & 0.94 & 1.43 & 3.28 & 3.55 & 3.10 \\
Chlorogenic acid & ND & ND & 0.37 & ND & 0.19 & 0.28 \\
Ellagic acid & ND & 1.88 & 2.14 & 1.88 & 2.61 & 2.21 \\
Kaempferol-3-G & 0.50 & 1.05 & 1.61 & 1.19 & 1.45 & 1.00 \\
Theaflavine & ND & ND & ND & ND & 0.56 & 0.48 \\
Caffeine & 27.47 & 41.46 & 39.76 & 34.77 & 41.63 & 27.08 \\
\hline
\end{tabular}

Notes: CG, catechin gallate; DW, dry weight; EC, epicatechin; ECG, epicatechin gallate; EGC, epigallocatechin; EGCG, epigallocatechin gallate; GC, gallocatechin; GCG, gallocatechin gallate; ND, not detected. Gongmei tea, Dianqing tea, Junshan Yinzhen tea, Fenghuang Shuixian tea, Yichang Congou tea, and Fuzhuan Brick tea are produced in Fujian, Yunnan, Hunan, Guangdong, Hubei, and Hubei provinces in China, respectively.

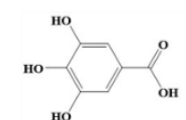

Gallic acid

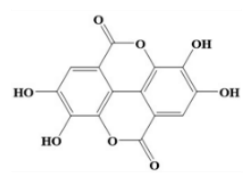

Ellagic acid

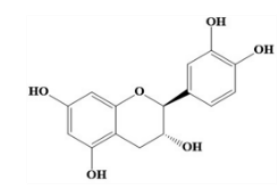

$(+)$-Catechin

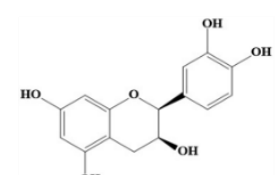

$(-)$-Gallocatechin

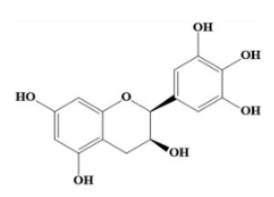

(-)-Epigallocatechin

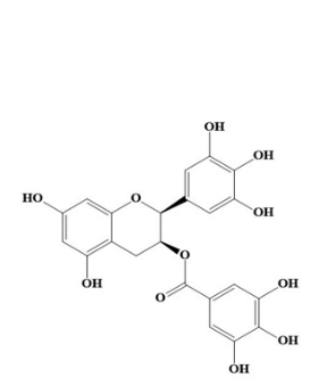

(-)-Epigallocatechin gallate

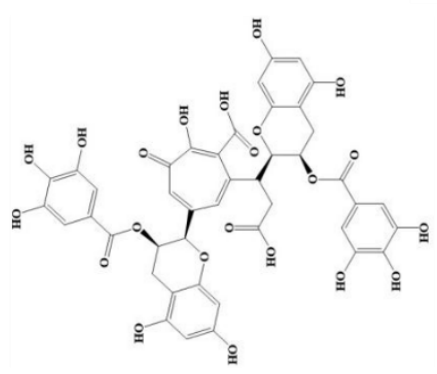

Thearubigin

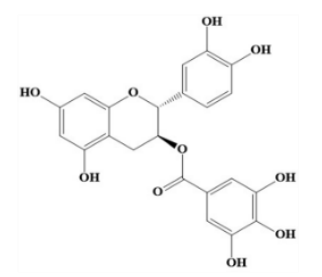

(-)-Catechin gallate

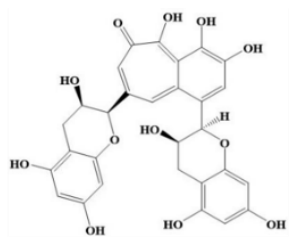

Theaflavin

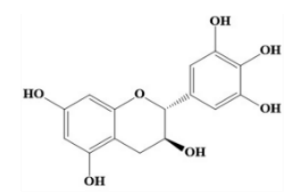

(-)-Epicatechin

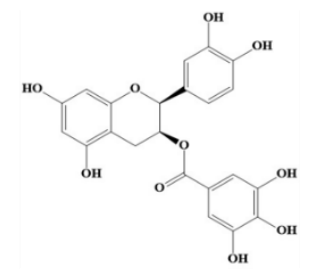

(-)-Epicatechin gallate

Figure 2. Chemical structures of several bioactive compounds in tea.

\section{Bioavailability}

Tea and its bioactive components show various biological activities and health functions, which are strongly correlated with their bioavailability, which are used in this review to designates the quantity or fraction of the ingested dose that is available to organisms, tissues or cells. So far, investigations have mainly focused on the bioavailability of tea polyphenols, such as catechin, EC, ECG, EGC, and EGCG.

\subsection{Bioavailability of Tea Polyphenols}

Many factors, regarding absorption, metabolism, distribution and excretion in the body, can influence the bioavailability of tea polyphenols [23,58,59]. Generally, the bioavailability of tea 
polyphenols is relatively low, mainly due to the low rate of absorption through gastrointestinal tract [60]. For example, it was reported that $<2 \%$ of the EGCG dose given orally was available in the systemic blood in rats [60]. Whereas, the absorption rate of oolong and black tea polyphenols is higher than that of green tea polyphenols [61]. To be more specifically, except for a few phenolic compounds like chlorogenic acid that can be absorbed in the stomach, tea polyphenols are mainly absorbed in the intestine [62-65]. Thus, proposed strategy to enhance the absorption of tea polyphenols and subsequently improve their bioavailability should target on intestine. Moreover, tea polyphenols are degraded and catabolized before absorption in the intestine, especially in the small intestine, in which gut microbiota plays a crucial role in the metabolism of tea polyphenols [63-65]. Hydrolyzed, methylated, sulfated, and glucuronidated actions are deemed as the common process of tea polyphenol metabolism by gut microbiota [64-67]. Metabolites of tea polyphenols are transported in the circulatory system and distributed in a wide range of organs and tissues, in which they contribute to the health functions of tea. These metabolites are mainly excreted in the urine and feces with apparently high recovery rate and short terminal elimination half-life, which is also responsible for the low bioavailability of tea polyphenols $[59,68,69]$. Nevertheless, some internal organs can still be exposed to non-marginal doses of tea polyphenols and their metabolites up to $24 \mathrm{~h}$ and even $48 \mathrm{~h}$, partly explaining the health functions of tea $[64,69]$.

\subsection{Strategies to Increase Tea Polyphenol Bioavailability}

Tea polyphenols are unstable in oxygen, acidic, and alkaline environment. Overcoming of these may help to improve their bioavailability, so some techniques, like modification technology, capsule technology, and nanotechnology, have been applied to achieve this [20-24]. Modifying tea polyphenols with peracetate acid can protect the free hydroxyl groups surrounding the molecules, improving their stability, and consequently result in increased bioavailability [20]. Delivery systems using protein-, lipid-, and carbohydrate-based carriers and/or capsules can not only reduce the instability of tea components, but also enhance their solubility, ensure favorable slow and sustainable release, and elevate the permeation in the small intestine, resulting in an increased concentration in the plasma and improved bioavailability and biological efficacy [21-24]. Moreover, fermentation could significantly increase the bioavailability of oolong, black and dark teas compared with unfermented counterpart, which may attribute to metabolism of tea components during fermentation by microbes like bacteria, yeasts, and fungi [70]. Furthermore, some dietary factors, including sucrose, ascorbic acid, piperine, quercetin, red onion, and Dendropanax morbifera, have been found to improve the digestion, metabolism, absorption, plasma concentration, bioaccessibility, and elimination half-life of tea and its components, all of which lead to the elevated bioavailability [71-75].

\subsection{Factors That Reduce Tea Polyphenol Bioavailability}

There are some factors that may reduce the bioavailability of tea polyphenols, such as ingestion on a non-empty stomach or with dietary proteins. For example, the area under the plasma concentration-time curve in healthy humans consuming EGCG capsules on an empty stomach was 2.7 and 3.9 times higher than that in counterparts consuming EGCG capsules with a light breakfast $(p=0.044)$ or consuming EGCG embedded in the strawberry sorbet $(p=0.019)$, respectively [76]. Similar actions were also observed for the plasma maximum concentration and mean concentration during the dosing interval, indicating the inhibition of tea catechin absorption when it is consumed with breakfast or with strawberry sorbet [76]. These results are consistent with another study based on 30 healthy volunteers, demonstrating that greater bioavailability of tea catechins could be achieved by consuming the Polyphenon E (a decaffeinated and defined green tea catechin mixture) capsules on an empty stomach after overnight fasting [77]. Moreover, it was found that simultaneous ingestion of dietary proteins from milk, caseinate, or soy significantly reduced the bioavailability of galloylated catechins (ECG and EGCG) and total catechins from green tea in humans, though the bioavailability of nongalloylated catechins (EC and EGC) was increased [78]. The difference of galloylated and non-galloylated catechins 
in bioavailability could be because of some kind of competition between individual catechins, and the complexation of galloylated catechins with proteins could delay liberation/absorption of these catechins, which would promote the absorption of non-galloylated catechins. Furthermore, dietary pretreatment with green tea EGCG ( $3.2 \mathrm{mg} / \mathrm{g}$ diet) for 2 weeks reduced the bioavailability of subsequent oral bolus doses of EGCG in CF-1 mice [79].

In short, tea polyphenols generally have a relatively low bioavailability, which mainly involves the digestion, metabolism, absorption, distribution, and excretion in the body. Many factors can impact the bioavailability of tea and its bioactive components, such as their own physicochemical properties, fermentation techniques, dietary factors, dosing conditions, species diversity, and individual differences. On the other hand, it lacks evidence about the bioavailability of other components in tea brewing and its extract, such as pigments, polysaccharides, saponins, and amino acids in the literature. In the future, more attention should be paid to the bioavailability of other components of tea.

\section{Health Functions}

\subsection{Antioxidant Activity}

In the literature, some studies have reported the antioxidant activity of tea brewing, extract and its components, which may have the potential for management of oxidative stress-induced diseases [80-82].

\subsubsection{Antioxidant Activity In Vitro}

The antioxidant activity of tea brewing, extract and its components has been evaluated by several in vitro biological assay methods using cellular antioxidant activity (CAA), erythrocyte hemolysis, and plasma oxidation assays [80-82]. Zeng et al. assessed the CAA of 27 tea cultivars, and the CAA values were 37.7-134.3 $\mu \mathrm{mol}$ quercetin equivalent (QE)/g dry weight (DW) (11.4-40.6 mg QE/g DW) without phosphate buffer washing, and 25.3-75.4 $\mu \mathrm{mol}$ QE/g DW (7.6-22.8 mg QE/g DW) with phosphate buffer washing [80]. The CAA assay is a more biologically relevant method compared to the chemistry assays, since it considers the uptake, metabolism, and distribution of antioxidant components in cells [80]. Moreover, Liu and Huang assessed the antioxidant activity of black tea extract using erythrocyte hemolysis, plasma oxidation, and CAA assays, showing that black tea extract dose-dependently protected erythrocytes from 2, 2'-azobis (2-amidinopropane)-induced oxidative hemolysis and copper-induced plasma oxidation, and the tea pigments, especially thearubigins and theabrownins, mainly contributed to the antioxidant activity of black tea extract [81]. The mechanisms of the cellular antioxidant assay may include restraining the generation of reactive oxygen species (ROS) by inducing the antioxidant enzyme activities, decreasing thiobarbituric acid-reactive substances (TBARS) and peroxyl radicals by avoiding dichlorofluorescein oxidation, increasing $2^{\prime}, 7^{\prime}$-dichlorofluorescein production, and blocking lipid peroxidation of low-density lipoprotein (LDL) and high-density lipoprotein (HDL) [81].

\subsubsection{Antioxidant Activity In Vivo}

The antioxidant activity of tea extract and its component has also been investigated in vivo $[83,84]$. The water extracts of green, black and dark teas were found to improve the tolerance of Caenorhabditis elegans to the $\mathrm{Cr}^{6+}$-induced oxidative stress [83]. Among these teas, green tea extract showed antioxidant activity probably by regulating the dietary restriction and germline signaling pathways in C. elegans, but not the forkhead box $\mathrm{O}$ (FOXO) and mitochondrial respiratory chain signals [83]. In addition, green tea extract could improve the oxidative stress status in mice by increasing content of plasmatic $\mathrm{SH}$-groups like reduced glutathione (GSH) and improving antioxidant enzymes in tissues, including NADPH quinone reductase in liver and small intestine, thioredoxin reductase in small intestine and superoxide dismutase (SOD) in liver [84]. 


\subsubsection{Antioxidant Activity in Humans}

In humans, tea extract and its component have shown to protect against oxidative stress-related injury [85-87]. Administration of green tea extract prevented the oxidative stress-mediated by repeated cycle sprint tests in sprinters [85]. Yabukita and Benifuuki green tea could protect against cutaneous oxidative stress by increasing the radical scavenging activity of the skin [86]. In mildly hypercholesterolemic subjects, green and oolong tea extracts enriched with catechins could significantly improve the content of GSH and the activity of antioxidant enzymes, including SOD, catalase (CAT), glutathione peroxidase (GPX), and glutathione reductase (GR) [87].

Collectively, tea extracts show good antioxidant activity mainly due to its diverse antioxidant components, such as polyphenols, polysaccharides, and pigments, which can scavenge free radicals, deplete ROS, increase antioxidant contents, and enhance antioxidant enzyme activities.

\subsection{Anti-Inflammatory Activity}

The considerable anti-inflammatory activity of tea and its bioactive components has been demonstrated with insights into the multiple mechanisms of action, indicating the potential in treating and managing inflammatory related diseases [88].

\subsubsection{Anti-Inflammatory Activity In Vitro}

Several research groups have investigated the in vitro anti-inflammatory activity of tea and related mechanisms. Cyboran et al. illustrated that green tea extract exerted a strong anti-inflammatory activity on red blood cells with no evident toxic effect [89]. Ben Lagha and Grenier demonstrated that black tea theaflavins attenuated the virulence of Porphyromonas gingivalis, regulated the tight junction integrity of the gingival keratinocytes, and exhibited an anti-inflammatory activity, showing the potential of preventing and treating periodontal inflammatory disease, which had multiple mechanisms, including the downregulation of inflammatory factors by $P$. gingivalis-stimulated macrophages, such as interleukin (IL)-1, IL-6, tumor necrosis factor $\alpha$ (TNF- $\alpha$ ), chemokine (C-X-C) ligand 8, matrix metalloprotease (MMP)-3, MMP-8, and MMP-9, attenuation of the P. gingivalis-induced activation of the nuclear factor $\mathrm{KB}(\mathrm{NF}-\mathrm{KB})$ signaling pathway, and inhibition of the gelatin degradation mediated by MMP-9 [90]. In addition, green tea supplements offered an anti-inflammatory effect in primary human rheumatoid arthritis synovial fibroblasts, in which catechins (EC, EGC, and EGCG) from green tea were found to have different impacts [91]. EGCG and EGC restrained IL-6, IL-8, and MMP-2 production and selectively suppressed COX-2 expression, while EC did not show any inhibitory activity on these factors. The three catechins could block the key signaling protein in the IL- $1 \beta$-signaling pathway, namely TAK-1, the transforming growth factor (TGF)- $\beta$-activated mitogen-activated protein kinase (MAPK). But only EGCG was able to occupy the major part of the active site of TAK-1. Moreover, EGCG could also inhibit the protein expression of $\mathrm{p} 38$ and NF- $\mathrm{KB}$, whereas EC and EGC did not. These results suggest that EGCG and EGC can be the main contributors to the anti-inflammatory effect of green tea, and EGCG is the most powerful catechin to inhibit the downstream signaling of inflammation.

\subsubsection{Anti-Inflammatory Activity In Vivo}

The protective activity of tea against inflammation has been further assessed in vivo $[17,92,93]$. Ramadan et al. investigated the anti-inflammatory activity of green tea extracts (rich in catechins) and black tea extracts (rich in theaflavins and thearubigins) in adjuvant-induced arthritic rats with two doses $(0.5$ and $1.0 \mathrm{~g} / \mathrm{kg} \mathrm{BW})$, and found that green tea extracts at $1.0 \mathrm{~g} / \mathrm{kg}$ remarkably alleviated arthritis in rats, accompanied with ameliorating synovial joint inflammation, elevating erythrocyte sedimentation rate, and restoring weight/cellularity of lymphoid organs [17]. These effects might be mediated by the downregulation of systematic pro-inflammatory cytokines and synovial tissue chemokine receptor-5. Additionally, Liu et al. reported that 4-week pretreatment with tea polyphenols $(300 \mathrm{mg} / \mathrm{kg}$ BW) significantly alleviated the inflammation mediated by acute exhaustive exercise in rats, 
and the serum levels of pro-inflammatory factors including TNF- $\alpha$, IL-1 $1 \beta$, and IL- 6 were significantly reduced in rats fed with tea polyphenols, accompanied with a shift of the serum IL-10/TNF- $\alpha$ ratio to a predominantly anti-inflammatory milieu and a suppression of IL-1 $\beta$ mRNA expression in the liver [92]. Moreover, green and black teas $(70 \mathrm{mg} / \mathrm{kg} B W)$ and their related components, such as EGCG $(10 \mathrm{mg} / \mathrm{kg}$ BW), theaflavins ( $9 \mathrm{mg} / \mathrm{kg} \mathrm{BW})$, and caffeine (18 mg/kg BW), effectively protected against murine sepsis, which could lie in modulating neutrophil influx and preventing neutrophil accumulation in lungs, decreasing systematic TNF- $\alpha$ and IL-6, suppressing tissue inducible nitric oxide synthase (iNOS) and COX-2, and increasing IL-10 [93].

\subsubsection{Anti-Inflammatory Activity in Humans}

Recent clinical trials have investigated the anti-inflammatory effect of tea [94-96]. A randomized, double-blinded, placebo-controlled clinical trial indicated that the daily consumption of green tea extracts (1000 mg, two capsules/day) for 12 weeks significantly improved the systemic lupus erythematosus (SLE) disease as well as the corresponding vitality and general health [94]. The results from another clinical trial suggested that green tea (tea leaves, $12 \mathrm{~g} /$ day) and coffee (approximately $300 \mathrm{mg} /$ day) had similar effects regarding decreasing plasma levels of inflammatory factors, such as IL-6 and NF- $\mathrm{KB}$, in soldiers with sleep deprivation, but green tea had the advantage of maintaining this effect [95]. However, it seemed that the acute ingestion of green tea and carbohydrate (catechins, $22 \mathrm{mg} / \mathrm{kg}$ BW; caffeine, $6 \mathrm{mg} / \mathrm{kg}$ BW; glucose, $230 \mathrm{mg} / \mathrm{kg} \mathrm{BW;} \mathrm{fructose,} 110 \mathrm{mg} / \mathrm{kg}$ BW) did not evidently improve inflammatory biomarkers during sprint cycling in athletes in comparison to carbohydrates (glucose, $230 \mathrm{mg} / \mathrm{kg}$ BW; fructose, $110 \mathrm{mg} / \mathrm{kg} \mathrm{BW}$ ) [96].

In short, tea extracts and its bioactive components possess strong anti-inflammatory activity, thus can be a potential agent for arthritis, sepsis, and SLE, with the mechanisms mainly including the regulation of pro-inflammatory and anti-inflammatory factors, like interleukins, chemokines, TNF- $\alpha$, NF- $\mathrm{kB}$, and COX-2, as well as the related signaling pathways.

\subsection{Immuno-Regulatory Activity}

The immuno-regulatory activity of tea brewing, extract and its bioactive components has been widely evaluated, with the mechanisms of action discussed below.

\subsubsection{Immuno-Regulative Activity In Vitro}

The disequilibrium of different $\mathrm{CD} 4^{+}$T-cell subpopulations, including Th1, Th2, Th17, and Treg cells with specific function in immune and inflammatory responses, plays a crucial role in the pathogenesis of autoimmune diseases. EGCG has been reported to inhibit the multiplication and cell cycle progression of naive $\mathrm{CD} 4^{+} \mathrm{T}$-cells, and to block naive $\mathrm{CD} 4^{+} \mathrm{T}$-cell differentiation into Th1 and Th17 effector subsets [97]. In another in vitro study, the results suggested that anthocyanins-enriched tea also exhibited immuno-stimulatory activity [98].

\subsubsection{Immuno-Regulative Activity In Vivo}

Tea and its bioactive components also exhibit systematic and peripheral immuno-regulatory activities in vivo. Wang et al. reported that the immunity of dairy cows was improved after a 6-week administration of tea saponins (0, 20,30, and $40 \mathrm{~g} / \mathrm{d})$ [11]. Sharma et al. declared that EGCG $(100 \mathrm{mg} / \mathrm{kg}$ $\mathrm{BW})$ from green tea enhanced the systemic immunity in aged male Swiss albino mice by improving the cellular immune response and simultaneously alleviating the antibody response aided by increased adrenal dehydroepiandrosterone [99]. It was observed that EGCG remarkably increased the plasma dehydroepiandrosterone level, the eosinophil and monocyte accounts in blood, the fraction of $\mathrm{CD}^{+}$ $\mathrm{CD}^{+}$cells in splenocytes, and the CD28 expression on peripheral blood mononuclear cells, while

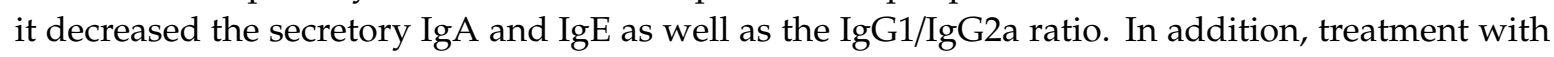
5 -( $3^{\prime}, \mathrm{S}^{\prime}$-dihydroxyphenyl)- $\gamma$-valerolactone (10 mg/kg BW), the major metabolite of EGCG, not only increased the activity of $\mathrm{CD} 4^{+} \mathrm{T}$-cells but also enhanced the cytotoxic activity of natural killer (NK) 
cells [100]. Moreover, black tea (10.48 mg solid content $/ \mathrm{kg} \mathrm{BW)} \mathrm{showed} \mathrm{a} \mathrm{protective} \mathrm{effect} \mathrm{on} \mathrm{the}$ peripheral immune responses in rats injected with intracerebroventricular colchicine, regarding higher phagocytic activity of the white blood cells and the splenic polymorphonuclear cells, and higher cytotoxicity and lower leukocyte adhesion inhibition index of the splenic mononuclear cells [101]. Furthermore, Ahmed et al. demonstrated that green tea by-products (contain 9.22\% moisture, 20.1\% crude protein, $2.91 \%$ crude fat, $18.2 \%$ crude fiber, $4.88 \%$ crude ash, $33.2 \%$ nitrogen-free extract, and $11.6 \%$ catechins) supplemented at the ratio of $0.5 \%, 1.0 \%$, or $2.0 \%$ in diet positively modulated the proliferation of immune cells in goats in a linear mode [102]. On the other hand, tea can interact with other natural products to regulate the immune response $[50,103]$. In one study, the mixture of green tea and grape seed extract (100: $200 \mathrm{mg} / \mathrm{kg} \mathrm{BW}$ ) relieved the immune suppression induced by $\gamma$-irradiation in male rats, showing radioprotective effect [103]. In another study, the combined administration of green tea Se-TPS and Huo-ji polysaccharides $(1: 1,300 \mathrm{mg} / \mathrm{kg} \mathrm{BW})$ exerted synergistic effects on improving the immune function in mice [50].

\subsubsection{Immuno-Regulative Activity in Humans}

In a human study, green tea polyphenol administration $(2 \times 350 \mathrm{mg} /$ day, for 14 days $)$ has been reported to decrease the level of IgE in patients with allergic rhinitis compared with those in the control group, though not statistically significant [104]. Since evidence is limited, more clinical trials are warrant in this field to further elucidate the immuno-regulative activity of tea extracts and its components.

In summary, tea extracts and its bioactive components, especially catechins, possess immuno-regulatory activity to improve both systematic and peripheral immunity, mainly by modulating immune cell proliferation, differentiation, activation, and alleviating antibody response, as well as regulating the hypothalamus-pituitary-adrenal (HPA) axis. Although tea does not have an evident effect on allergic rhinitis, it has the potential to manage immune-mediated diseases like autoimmune and encephalomyelitis.

\subsection{Anticancer Effect}

\subsubsection{Anticancer Effect In Vitro}

The anticancer activity of tea extracts and its components has been widely investigated in vitro. Park et al. reported that green tea rhamnogalacturonan-II-type polysaccharide (GTR-II) could inhibit tumor metastasis [44]. GTR-II enhanced the tumoricidal activity of macrophages and NK cytotoxicity against Yac-1 tumor cells. On the other hand, injection of rabbit anti-asialo GM1 serum could lead to the depletion of NK cells, which in turn eliminated the prohibitory activity of GTR-II on B16BL6 melanoma cells. These results together indicate that the anticancer effect of GTR-II can be mediated by the activated macrophages and NK cells. Krstic et al. demonstrated that green tea extracts possessed anticancer activity on HeLa human cervical adenocarcinoma cells, which depended on the pro-oxidant and anti-proliferative activities of polyphenols [105]. Furthermore, tea components have different effects on cancer cells and normal cells. It was shown that black tea pigments exerted potent inhibitory activity against cisplatin-resistant ovarian cancer cells, while they were less cytotoxic to normal ovarian cells, with the mechanisms involving the induction of G1 cell cycle arrest by down-regulating cyclin-dependent kinase (CDK) 2, CDK4, and cyclin E1, and mediating apoptosis through p53-dependent, ATM/Chk/p53, Akt, and MAPK pathways [10]. In another study, EGCG showed different pro-oxidative effects on normal and oral cancer cells, which was correlated with a different regulation of the sirtuin (SIRT)-3 pathway [106]. ROS in mitochondria was induced by EGCG in SCC-25 and SCC-9 human oral squamous carcinoma cells and MSK-Leuk1 premalignant leukoplakia cells, but not in HGF-1 normal human gingival fibroblast cells. In addition, EGCG inhibited SIRT-3 mRNA and protein expression as well as SIRT-3 activity, reduced the nuclear localization of estrogen-related receptor $\alpha$, a SIRT-3 transcription regulator in SCC-25 cells, while enhanced SIRT-3 activity in HGF-1 cells. Moreover, EGCG could differentially modulate the mRNA expression of 
SIRT-3-associated downstream antioxidant-responsive genes, including GPX1 and SOD2, in oral cancer cells and normal cells, with the related molecular mechanisms shown in Figure 3.

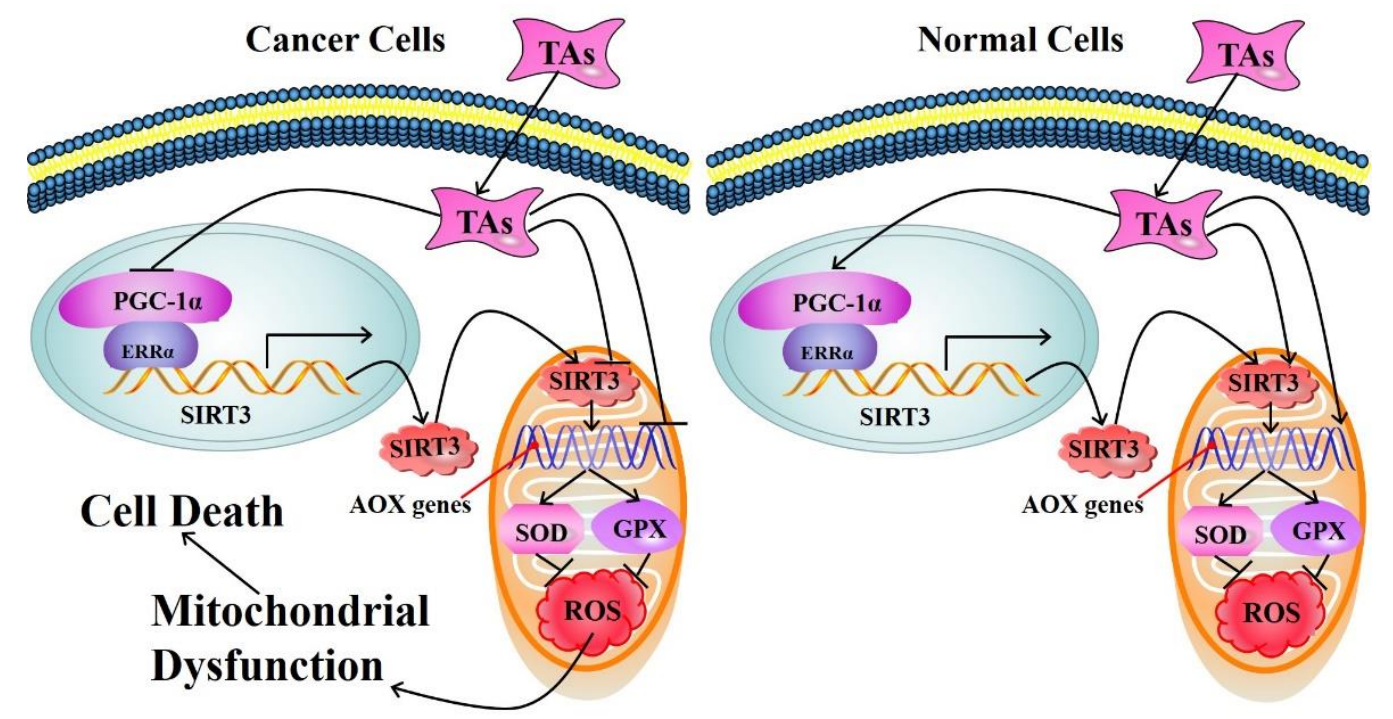

Figure 3. The molecular mechanisms of tea antioxidants (TAs) with contrasting influences on cancer and normal cells. In cancer cells, TAs inhibit the expression and activity of sirtuin 3 (SIRT3), leading to mitochondrial reactive oxygen species (ROS) accumulation, mitochondrial dysfunction, and ultimately cell death. In normal cells, TAs activates SIRT3 and related downstream antioxidant responsive genes (AOX genes, including superoxide dismutase 2 (SOD2) and glutathione peroxidase 1 (GPX1)), preventing cells from oxidative damage. Abbreviations: $\mathrm{ERR} \alpha$, estrogen-related receptor $\alpha$; PGC- $1 \alpha$, peroxisome proliferator-activated receptor $\gamma$ coactivator $1 \alpha$.

\subsubsection{Anticancer Effect In Vivo}

Tea and its components also exhibited anticancer activity in vivo [3,107-109]. Calgarotto et al. found that green tea $(100 \mathrm{mg} / \mathrm{kg} \mathrm{BW})$ possessed anticancer effect in HL-60 human leukemia xenograft mice, by reducing tumor growth via mediating G1 phase cell cycle arrest, mediating apoptosis via the regulation of caspase-3, Bcl-2 (B-cell lymphoma 2), Bcl-xL (B-cell lymphoma-extra large), Bax (Bcl-2-associated X protein), MCL-1, LC3-I, and LC3-II, and initiating autophagic progression via the activation of autophagy proteins [107]. Torello et al. reported that green tea ( $250 \mathrm{mg} / \mathrm{kg} \mathrm{BW})$ could induce anti-leukemic activity in an acute promyelocytic leukemia model, which was triggered by the production of ROS, activation of caspase-3/8/9, and nuclear translocation of HIF-1 $\alpha$ [108]. In addition, green tea polyphenon-60 (250 mg/kg BW) exerted an apoptogenic effect against Ehrlich's ascites carcinoma cells in Swiss albino mice [109]. Moreover, Kujawska et al. demonstrated that yellow tea extract $(10 \mathrm{~g} / \mathrm{kg}$ feed) protected the liver of rats from $\mathrm{N}$-nitrosodiethylamine-induced hepatocarcinogenesis via its antioxidant effect as revealed by the reversion of SOD, CAT, GPX, paraoxonase 1, and reduced glutathione (GSH), which in turn decreased lipid peroxidation, protein carbonyl formation, and DNA degradation [3].

\subsubsection{Anticancer Effect in Humans}

Several clinical trials also demonstrated the anticancer effect of tea and its components [110-112]. It was reported that green tea consumption $(5 \times 1$ cup/day, four weeks) changed oral bacteria, which might be related to oral carcinogenesis [110]. In another clinical trial involving 70 Algerian prostate cancer patients and 120 age-matched healthy subjects, daily consumption of 5 cups of infusion prepared from $2 \mathrm{~g}$ green tea for 6 months significantly decreased oxidative stress and prevented prostate cancer initiation [111]. On the other hand, in a short-term double-blinded placebo-controlled phase II clinical trial with 60 high-grade prostate intraepithelial neoplasia patients, consumption of green tea catechins 
$(600 \mathrm{mg} / \mathrm{d})$ showed no significant difference in prostate cancer incidence between the experimental and control groups after 6 and 12 months, but a non-significant improvement in lower urinary tract symptoms and a better quality of life with very limited adverse effects were observed [112]. Therefore, additional clinical trials are necessary to investigate the anticancer effect of tea.

\subsubsection{Strategy to Improve Anticancer Effect of Tea and Its Component}

Combinational therapies for cancer treatment have attracted increasing attention due to the inefficiency of single-drug treatment $[113,114]$. Synergistic effects may result in the enhanced anticancer activity of tea bioactive components. For instance, it was observed that oolong tea polyphenols and polysaccharides with high molecular weight had synergistic anticancer activity on hepatocellular carcinoma by inhibiting the proliferation and growth of cancer cells [113]. Dietary tea polyphenols also exerted a synergistic anticancer activity with bleomycin hydrochloride in human cervical cancer cells, through caspase-dependent and independent apoptotic pathways [114]. Moreover, the clinical success of using natural ingredients depends on efficient systemic delivery and bioavailability [115-117]. Singh et al. reported that poly (lactide-co-glycolide)-encapsulated tea polyphenols (theaflavin and EGCG) offered an up to 7-fold dose advantage regarding anti-proliferative activity in comparison to bulk theaflavin and EGCG, and also enhanced the apoptosis of cisplatin in different human cancer cells, like A549 lung carcinoma cells, HeLa cervical carcinoma cells, and THP-1 acute monocytic leukemia cells [115]. Mechanisms of action included the inhibition of NF- $\mathrm{kB}$ activation, induction of the cleavage of caspase-3/9 and Bax/Bcl2 ratio in favor of apoptosis, and inhibition of the expression of cyclin D1, MMP-9, and vascular endothelial growth factor (VEGF) that refers to cancer cell proliferation, metastasis, and angiogenesis, respectively. In addition, Mukherjee et al. reported that gold-conjugated green tea nanoparticles possessed more potent anticancer effect. The nanoparticles transformed the redox status, inhibited the Nrf2 (nuclear factor erythroid 2-related factor 2) activation, reduced the phosphorylation of I $\mathrm{kB}$, blocked the nuclear translocation of NF- $\mathrm{kB}$, and suppressed the NF- $\mathrm{kB}$-dependent anti-apoptotic proteins Bcl2 and Akt, all of which triggered the onset of apoptosis in cancer cells [116].

Overall, tea extracts and its components have shown protective effects against liver cancer, breast cancer, ovarian cancer, cervical cancer, prostate cancer, and leukemia, involving inhibiting initiation, proliferation, growth, resistance, metastasis, and angiogenesis, as well as inducing apoptosis, autophagy, and degradation of cancer cells, and related molecular targets are shown in Figure 4. 


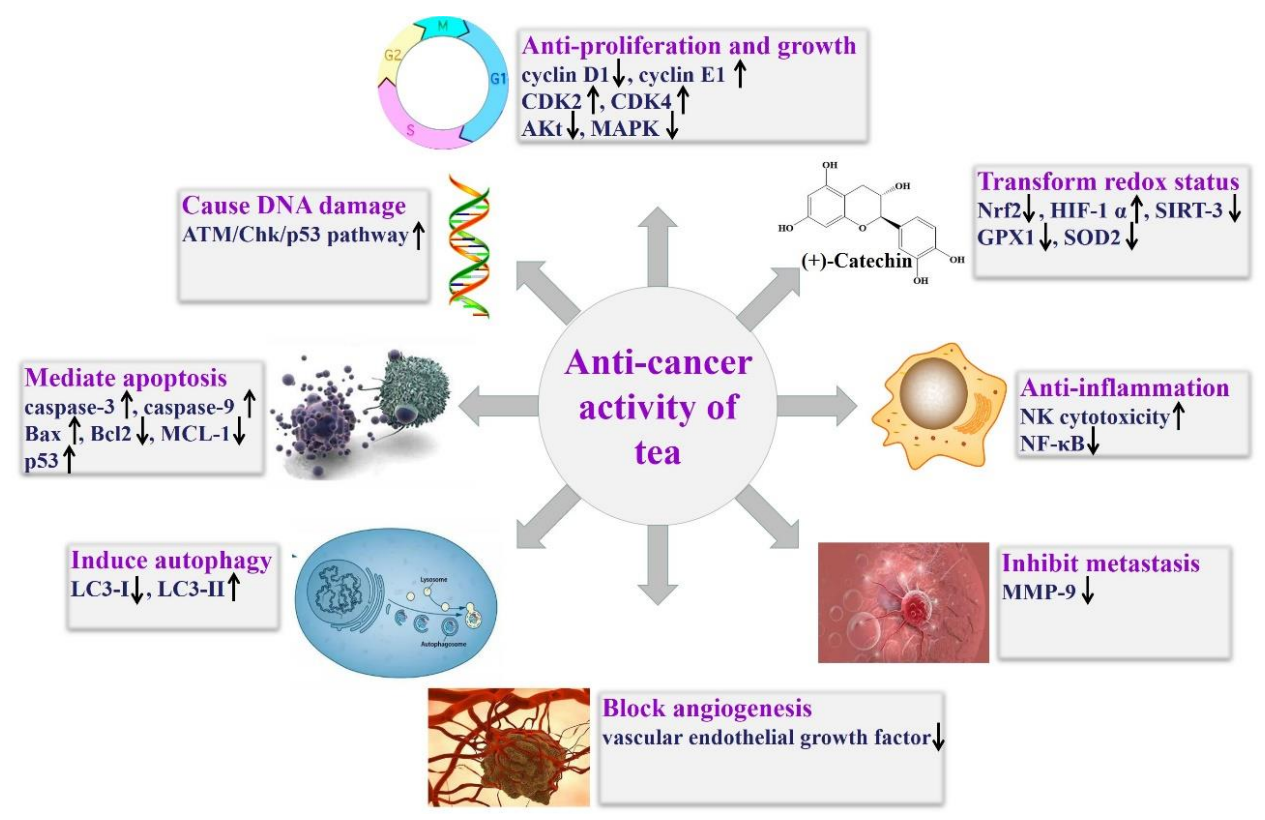

Figure 4. Main molecular targets of tea on targeting cancer. Abbreviations: Akt, protein kinase B; Bax, Bcl-2-associated X protein; Bcl-2, B-cell lymphoma 2; CAT, catalase; CDK, cyclin-dependent kinase; GPX, glutathione peroxidase; IL, interleukin; MAPK, mitogen-activated protein kinase; MCL-1, myeloid cell leukemia 1; MMP, matrix metallopeptidase; NF- $\mathrm{B}$, nuclear factor $\mathrm{\kappa B}$; NK, natural killer; SIRT, sirtuin; SOD, superoxide dismutase.

\subsection{Cardiovascular-Protective Effect}

Several epidemiological studies and meta-analyses suggest that tea brewing consumption is negatively correlated to the risk of CVD, such as hypertension, atherosclerosis, coronary heart disease, and angina $[118,119]$. Considering the Japanese Paradox, lower serum cholesterol level in the past Japanese middle-aged and elderly people compared to Western counterparts could help to maintain the low coronary heart disease incidence and mortality, in which reduced blood pressure level and smoking rate for both men and women also plays an important role. These can be helpful to explain the cardiovascular-protective effect of tea brewing and its components by targeting hyperlipidemia and hypertension [120].

\subsubsection{Cardiovascular-Protective Effect In Vitro}

In an in vitro study, it was shown that Pu-erh tea (a kind of post-fermentation dark tea [7]) aqueous extract (PTAE) could regulate blood lipid metabolism enzymes, thereby ameliorating hyperlipidemia [121]. PTAE dose-dependently inhibited the activities of 3-hydroxy-3-methyl- glutaryl coenzyme A reductase (HMGR) and pancreatic lipase (PL) (PTAE acted as a competitive inhibitor) and lipoprotein-associated phospholipase A2 (Lp-PLA2) (PTAE acted as a non-competitive inhibitor), and increased the activity of lecithin:cholesterol acyltransferase (LCAT). In another study, Lung Chen Tea (a green tea) significantly inhibited endothelial cell-induced LDL oxidation as revealed by the reduced lipid peroxidation products, TBARS, and cellular cholesterol, thus may decrease the risk of coronary heart diseases [122]. Moreover, oolong tea extract was found to attenuate p-JNK (c-Jun N-terminal kinases) mediated hypertrophy, to suppress caspase-3-cleavage and apoptosis, to enhance the activities of IGF1R, Akt, and Bad, and to improve the Nrf2-mediated antioxidant system, all of which led to the prevention of cardiomyocyte loss against hypoxia [123].

\subsubsection{Cardiovascular-Protective Effect In Vivo}

Tea and its components have been reported to lower blood pressure by some in vivo studies using animal models. Garcia et al. reported that intake of green tea (9.6 g in $1.0 \mathrm{~L}$ water; $18 \mathrm{~mL} /$ day) 
could reduce blood pressure, inhibit renal sympathetic nerve activity, improve arterial baroreceptor function, and ameliorate vascular and systemic oxidative stress in rats with hypertension induced by $\mathrm{N}$-nitro-L-arginine-methyl-ester [124]. Moreover, the consumption of green tea extract $(2 \mathrm{and} 4 \mathrm{~g} / \mathrm{kg}$ diet) was observed to benefit blood pressure and to improve inflammation and antioxidant status in $\mathrm{NaCl}$-induced hypertensive rats [125]. However, results from another animal study argued that heavy tea consumption might be unsuitable for hypertensive subjects [126]. It was found that feeding of tea extract $(300 \mathrm{mg} / \mathrm{kg} \mathrm{BW})$ induced an acute increase in systolic/diastolic blood pressure and heart rate in spontaneously hypertensive rats, which might be mediated by regulating plasma epinephrine and norepinephrine levels. Therefore, moderate tea consumption can be beneficial to hypertensive patients, but excessively heavy tea consumption might be harmful.

Some animal studies also demonstrated that tea and its extract also exerted protective effect against hyperlipidemia. For instance, aqueous extracts from fermented Pu-erh tea (150, 300, and $900 \mathrm{mg} / \mathrm{kg} \mathrm{BW}$ ) were shown to exhibit certain anti-hyperlipidemia effects in rats [127]. In addition, dried green tea leaves were mixed with $1 \%$ sucrose and $5 \times 10^{7}$ colony-forming unit of Bacillus subtilis and fermented at $50{ }^{\circ} \mathrm{C}$ for $3 \mathrm{~d}$, followed by further incubation at $90^{\circ} \mathrm{C}$ for $4 \mathrm{~d}$ to remove remaining B. subtilis [128]. The results showed that the extracts $(500 \mathrm{mg} / \mathrm{kg} \mathrm{BW})$ of fermentation of green tea exhibited a hypolipidemic effect by inhibiting PL, promoting energy expenditure, and reducing the proportion of the Phylum Firmicutes in the gut microbiota. Moreover, TPS ( $6.9 \mathrm{~g} / 100 \mathrm{~g}$ diet) from green tea showed to suppress liver lipid accumulation and increase fecal excretion of dietary fat, which might help to reduce hyperlipidemia [129]. Meanwhile, TPS (100, 300, and $500 \mathrm{mg} / \mathrm{kg} \mathrm{BW)} \mathrm{from}$ Liupao tea (dark tea) dose-dependently increased antioxidant enzyme activities, ameliorated lipid oxidation, and improved the lipid profile in rats [130]. Besides, tea polyphenols (100 mg/kg BW) reduced lipid absorption by inhibiting lipase in the intestinal mucosa and contents, thus helped to prevent hyperlipidemia in rats treated with olive oil [131].

In the animal studies, tea consumption could ameliorate endothelial dysfunction and consequently benefit the vascular health [132-134]. Daily consumption of black tea $(15 \mathrm{mg} / \mathrm{kg}$ BW, 4 weeks; active ingredients as theaflavins) exerted beneficial effects to reverse endothelial dysfunction in ovariectomized SD rats [132]. The mechanisms may involve improving flow-mediated dilatation in small mesenteric resistance arteries, augmenting acetylcholine (ACh)-induced endothelium-dependent relaxations in aortae and renal arteries, elevating ACh-stimulated cyclic guanosine monophosphate (cGMP) production in aortae, as well as restoring the phosphorylation of endothelial nitric oxide synthase (eNOS), the up-regulation of NADPH oxidases, and the overproduction of ROS in aortae. In addition, daily green tea EGCG treatment (50 mg/kg BW, 10 weeks) could improve endothelial function in high-fat diet-fed male C57BL/6J mice, by promoting insulin-stimulated vasodilation, restoring insulin-stimulated phosphorylation of eNOS, insulin receptor substrate-1, and Akt in primary bovine aortic endothelial cells, as well as reducing macrophage infiltration into aortic tissues [133].

\subsubsection{Cardiovascular-Protective Effect in Humans}

Tea consumption can also reduce the risk of CVD in humans. It was reported that short-term daily consumption of three capsules containing $500 \mathrm{mg}$ of green tea extract could reduce blood pressure in obese prehypertensive women [135]. In addition, tea consumption also improved the endothelial function in humans, and green and black teas may be equally effective with regard to improve endothelial function [136-140]. Acute black tea intake (200 mL/day) for seven days enhanced the cutaneous vascular response to gradual local heating to $42{ }^{\circ} \mathrm{C}$ in healthy, middle-aged participants, which was probably induced by activating endothelium-derived chemical mediators like NO [136]. The intake of black tea (with $150 \mathrm{mg}$ polyphenols), twice a day for eight days, protected blood vessels in hypertensive patients through augmenting the amount of circulating angiogenic cells and blocking endothelial dysfunction [137]. Green tea catechins ( $580 \mathrm{mg} /$ day, 2 weeks) improved human forearm endothelial dysfunction and exerted an antiatherosclerotic effect in smokers [138]. Green tea (equivalent to $200 \mathrm{mg}$ EGCG/d) treatment was also observed to improve the endothelial function in humans in terms 
of flow-mediated dilation. However, its isolated EGCG might not contribute to this improvement [139]. Furthermore, tea consumption also reduced hyperlipidemia in humans [141,142]. Treatment with four green tea extracts capsules containing $1315 \mathrm{mg}$ catechins (843 mg EGCG) daily for 12 months gave rise to a significant reduction of blood total cholesterol (TC) and LDL-cholesterol (LDL-C) levels, particularly in subjects with increased baseline TC level [141]. Similarly, daily consumption of functional black tea (with $2 \mathrm{~g}$ phytosterols) remarkably reduced the TC, LDL-C, and apolipoprotein B levels, as well as oxidative stress index in mild hypercholesterolemia subjects, while increased adiponectin and tissue-plasminogen activator and improved total antioxidant status [142]. However, in a diet-controlled randomized trial, daily intake of 5 cups of black tea had no significant alteration on the lipid profile of borderline hypercholesterolemic subjects [143].

Collectively, tea beverage consumption can decrease CVD risk, mainly by improving redox status, inhibiting inflammation, decreasing blood pressure, ameliorating hyperlipidemia, regulating endothelial function, preventing myocardial damage, and regulating sympathetic nerve activity. However, due to inconsistent results of human studies, more clinical trials that are rationally designed and accurately conducted are necessary to verify the cardiovascular-protective effect of tea.

\subsection{Anti-Diabetic Effect}

Postprandial hyperglycemia is one of the symptoms of type 2 diabetes mellitus (T2DM), and tea beverage consumption has been reported to ameliorate hyperglycemia, thus providing benefits to T2DM patients [144].

\subsubsection{Anti-Diabetic Effect In Vitro}

Tea has been found to inhibit $\alpha$-glucosidase, delay glucose absorption and reduce hyperglycemia in vitro [144-146]. Green, oolong, and black tea extracts exerted inhibitory activity against $\alpha$-glucosidase, and green tea extracts exhibited the strongest effect [144]. Black tea aqueous extract significantly suppressed $\alpha$-glucosidase activity and showed a mixed-type inhibitory activity with acarbose [145]. In addition, TPS was observed to inhibit $\alpha$-glucosidase, which could be enhanced by removing the metal ions from the TPS [43,146]. Moreover, type II arabinogalactan, a water-soluble polysaccharide from green tea, could regulate the cyclic adenosine monophosphate-protein kinase A (cAMP-PKA) pathway and, correspondingly, significantly enhance glucose-stimulated insulin secretion in RIN-5F cells at a high glucose level ( $25 \mathrm{mM})$, but no effect was found at a low glucose level (5 mM) [47].

\subsubsection{Anti-Diabetic Effect In Vivo}

Considering the health functions as shown in vivo, tea might serve as a functional food and pharmaceutical for the prevention and treatment of T2DM. Satoh et al. reported that black tea aqueous extract inhibited the hydrolysis of disaccharides into monosaccharides by the $\alpha$-glucosidase in the small intestine, thereby blocking the sodium-dependent glucose cotransporter 1 and glucose transporter (GLUT) 2-mediated absorption of the dietary glucose [31]. Li et al. declared that TPS treatment could alleviate insulin resistance and decrease blood glucose in diabetic mice, which might be mediated by the regulation of the PI3K/Akt signal pathway as revealed by the up-regulated expression of PI3Kp85/p-Akt/GLUT4-signaling molecules [147]. Additionally, various kinds of tea might have different anti-hyperglycemic strength, and yellow tea might be a better choice compared to green and black teas [148]. In another study, mixtures of dried green tea leaves and Aquilariae lignum powder at weight ratio of $49: 1$ were wet-fermented for $12 \mathrm{~h}$ at $60^{\circ} \mathrm{C}$ and steamed for $30 \mathrm{~s}$ at $100{ }^{\circ} \mathrm{C}$ after being dried for 1 week at $15^{\circ} \mathrm{C}$, then the steamed mixtures were cooled and additionally dried at $15^{\circ} \mathrm{C}$ for 3 days [149]. The results showed that fermentation of green tea increased the anti-diabetic activity of green tea aqueous extracts in mouse fed with high fat diet, as revealed by the stronger hypoglycemic effect resulted from stronger inhibitory activity on the hepatic glucose-regulating enzymes including glucokinase, glucose-6-phosphatase, and phosphoenolpyruvate carboxykinase. 


\subsubsection{Anti-Diabetic Effect in Humans}

Tea has shown promising efficacy in managing T2DM in several clinical trials, in terms of improving insulin resistance and postprandial hyperglycemia of humans. Consumption of black tea significantly reduced glycated hemoglobin $(\mathrm{HbA} 1 \mathrm{c})$ level and helped to decrease the risk of suffering from TD2M in subjects [150]. In addition, regular intake of green tea could benefit high-fat diet-induced T2DM [151]. Meanwhile, green tea was found to augment the isomaltulose activity to reduce postprandial glucose and insulin concentration in healthy subjects [152]. Furthermore, supplementation with green tea extract could improve glycemic control and prevent osteoporosis in diabetic patients [153].

Thus, tea consumption can be a promising strategy for preventing and treating diabetes and its complications by regulating glucose absorption and metabolism, controlling postprandial glucose level, and ameliorating insulin resistance.

\subsection{Anti-Obesity Effect}

Recent studies have suggested an anti-obesity effect of tea and its components, partially by improving energy expenditure, lipid metabolism, and lipid accumulation.

\subsubsection{Anti-Obesity Effect In Vitro}

Tea and its components could modulate the glycolipid digestion, absorption, and metabolism in vitro, resulting in a beneficial effect on obesity. White, green and black teas were found to effectively inhibit lipase activity, and dose-dependently reduce lipid deposition in cultured adipocytes [154]. In addition, a novel acylated flavonol tetraglycoside from $\mathrm{Lu}^{\prime}$ an GuaPian tea (a kind of green tea) remarkably inhibited the proliferation, differentiation, and lipid accumulation of 3T3-11 cells [33]. Total green tea polyphenols might exhibit a greater inhibitory effect than purified EGCG on adipogenesis in 3T3-11 cells, through decreasing adipogenic factors, including CCAAT element-binding protein $\alpha$, peroxisome proliferator-activated receptor $\gamma(\operatorname{PPAR} \gamma)$, and sterol regulatory element-binding protein-1c (SREBP-1c) [155].

\subsubsection{Anti-Obesity Effect In Vivo}

Some results from in vivo studies have provided significant insights into the effects of tea for the prevention of obesity and related comorbidities like metabolic syndromes. Choi et al. reported that green tea extracts could ameliorate obesity, hepatic steatosis, dyslipidemia, and insulin resistance in diet-induced obese mice [156]. Supplementation of tea extract resulted in reduced body weight gain and adiposity through enhancing energy expenditure. The transcriptome profiles of epididymal white adipose tissue indicated that green tea augmented energy homeostasis by enhancing transcriptional reaction to the degradation of branched-chain amino acids, and by regulating adenosine monophosphate-activated protein kinase (AMPK) signaling. Moreover, green tea could increase the hepatic lysophosphatidylcholine acyltransferase 2/4 and, correspondingly, attenuate the reduction of several lipid metabolites in mice fed with a high-fat diet, such as lysophosphatidylcholine, lysophosphatidylethanolamine, and lysophosphatidylserine [157]. Furthermore, it was also demonstrated that polyphenols and polysaccharides were the major components contributing to the inhibitory effects of green tea extracts on body weight gain and fat accumulation in rats fed with a high-fat diet [48].

Regulation of the gut microbiota in obese animals can be a crucial component of the mechanism of the responses contributing to the anti-obesity effects of tea. Consumption of green, oolong and black teas markedly augmented the diversity and shifted the structure of the gut microbiota in high-fat-induced obese mice, including 30 key phylotypes, such as Alistipes, Rikenella, Lachnospiraceae, Akkermansia, Bacteroides, Allobaculum, and Parabacteroides, which could be closely correlated to the obesity-associated indexes [158]. Moreover, the administration of oolong tea polyphenols could protect against the 
obesity-related metabolic disorders by improving the expression of genes involved in the amino acid biosynthesis and carbon metabolism, and by manipulating the intestinal microbiota [159]. In detail, the increased abundance of butyrate- and acetate-producing bacteria, the large increase in Bacteroidetes, the decrease in Firmicutes, and the correspondingly decreased Firmicutes/Bacteroidetes ratio suggested the protective effect. Moreover, green tea polyphenols significantly blocked diet-induced weight gain, fat deposition, adipocyte hypertrophy, and hepatic steatosis in C57BL/6J human flora-associated mice, possibly by modulating the diversity of gut microbiota and by increasing the abundance of lactic acid bacteria [160].

\subsubsection{Anti-Obesity Effect in Humans}

Tea has shown protective effects on obesity and related metabolic disorders in some clinical trials. It was reported that 12-week daily treatment with $856.8 \mathrm{mg}$ green tea extracts gave rise to a large reduction in body weight, waist circumference, and plasma TC and LDL levels in central-obese women, without any detected adverse effect [161]. The mechanism might partially be due to inhibition of the secretion of ghrelin and raising the level of adiponectin. Taghizadeh et al. demonstrated that daily consumption of a mixture containing $125 \mathrm{mg}$ green tea, $25 \mathrm{mg}$ capsaicin, and $50 \mathrm{mg}$ ginger extracts for eight weeks significantly reduced the weight, body mass index (BMI), plasma GSH level, and insulin metabolism markers in overweight women [162]. However, a 4-week decaffeinated green tea extract $(571 \mathrm{mg} / \mathrm{d}$ ) intervention did not alter total fatty acid concentrations in recreationally active males, although it enhanced substrate utilization and subsequent performance indices [163]. Furthermore, tea consumption in combination with exercise training might be a favorable strategy to control obesity. For instance, green tea supplementation (3 tablets of $500 \mathrm{mg}$ after each main meal) with high-intensity interval training for 10 weeks could distinctly reduce body weight, BMI, and the undesirable consequence of overweight, through augmenting the levels of SIRT- 1 and PPAR $\gamma$ co-activator 1- $\alpha$ [164]. In addition, a 12-week intervention with three green tea capsules containing $250 \mathrm{mg}$ of green tea extract (187.5 mg polyphenols, $125 \mathrm{mg}$ EGCG, and $20 \mathrm{mg}$ caffeine) daily and interval sprinting exercise significantly decreased body and abdominal fat, and increased total lean mass in overweight males [165].

In short, tea extract and its components, including polyphenols, caffeine and polysaccharides, showed potent anti-obesity effects, which could involve regulating glycolipid digestion, absorption, and metabolism, improving energy expenditure, preventing lipid accumulation and deposition, and ultimately reducing body weight gain and increasing lean mass.

\subsection{Hepato-Protective Effect}

Some natural products have been found to protect against liver injuries [166-170]. Tea has also shown a beneficial effect on diet- and chemical-induced disorders in liver, including hepatic oxidative stress damage, inflammation, steatosis, and fibrosis [41,171,172].

\subsubsection{Hepato-Protective Effect In Vitro}

The increase of ROS and the depletion of the antioxidant defense system could evoke apoptosis in cultured hepatocytes, but the pretreatment with gold-conjugated green tea nanoparticles protected hepatocytes from cellular damage, with the mechanisms of scavenging excessive ROS, enhancing the activity of antioxidant enzymes, augmenting GSH level, as well as reducing Bax/Bcl2 ratio and active caspase-3 levels [116].

\subsubsection{Hepato-Protective Effect In Vivo}

The hepato-protective effect of tea against chemical-induced liver injury was also demonstrated in several in vivo studies. White tea extract and the comparative dose of EGCG showed equivalent protective effects to attenuate benzo(a) pyrene-induced hepatic dysfunctions, in terms of increased biomarkers regarding inflammatory and oxidative stresses, decreased endogenous antioxidants, and the 
hepatic histoarchitectural alteration [172]. In addition, green tea could protect rats from alcohol-induced mitochondrial DNA damage, and could ameliorate oxidative stress by improving the activities of SOD, GPX, and CAT as well as increasing the content of GSH [173]. Moreover, theaflavin-enriched black tea extracts exerted a hepato-protective effect against dimethylnitrosamine-induced liver fibrosis in rats, probably via blocking the TGF- $\beta 1 /$ Smad signaling [41].

Tea also possessed a hepato-protective effect against diet-induced liver injury, in particular the non-alcoholic fatty liver disease (NAFLD) [171,174]. Besides improving oxidative and inflammatory status, mechanisms also involved: (1) Increasing energy expenditure via enhancing mitochondrial complex chain; (2) inhibiting fat synthesis via modulating the mRNA expression of SREBP-1c, cAMP-response element-binding protein regulated transcription coactivator 2, and stearyl coenzyme A dehydrogenase-1; (3) improving cholesterol homeostasis via regulating the mRNA expression of apolipoprotein B100 and ATP-binding cassette transporter A1; and (4) preventing gut dysbacteriosis [18,175,176].

\subsubsection{Hepato-Protective Effect in Humans}

Tea and its components have been considered as potential ingredients for ameliorating liver injuries in patients. In a double-blinded, placebo-controlled, randomized clinical trial, the green tea extract consumption ( $500 \mathrm{mg} /$ day, 90 days) successfully decreased the levels of liver enzymes including ALT, AST, and ALP in patients with NAFLD [177]. In another clinical trial with hypercholesterolemic subjects, catechin-enriched green and oolong tea treatments were found to significantly decrease body weight, BMI, fat, lipid peroxidation, and lipid profiles (TG, TC, LDL-C, and HDL-C), while improving GSH, SOD, CAT, GPX, and GR in the liver [87].

Collectively, tea and its components show a hepato-protective effect, as they could ameliorate oxidative stress via improving the antioxidant defense system, inhibit inflammation, block liver cell apoptosis, regulate lipid metabolism, prevent hepatic steatosis and fibrosis, and retard gut dysbacteriosis.

\subsection{Other Health Functions}

Tea also exhibits some other health functions in vitro and in vivo, as shown in Tables 2 and 3, respectively. For instance, tea could protect against kidney injuries induced by a high-fat diet, proline, gentamicin, lead, and ischemia-reperfusion [178-183]. In addition, tea has exhibited the neuro-protective effect, in terms of protecting against age-related neuro-degenerative disorders, depression and regulating the circadian clock [184-190]. Moreover, tea could inhibit gastric ulcer and improve gastrointestinal function [191-195]. Besides, tea could modulate gut microbiota composition (increase beneficial microorganisms and decrease harmful microorganisms), which might be beneficial to those in the risk of obesity, metabolic syndrome, hyperlipidemia, and cardiovascular diseases [196-202]. Furthermore, some studies have suggested the potent anti-bacterial, anti-fungal, and anti-viral activities of tea $[34,56,61,203-208]$.

Taken together, tea brewing, extract and its bioactive components possess diverse health functions (Figure 1), such as antioxidant, anti-inflammatory, immuno-regulatory, anticancer, cardiovascular-protective, anti-diabetic, anti-obesity, and hepato-protective effects. Specifically, consumption of tea and its bioactive components has been reported with the potential to manage certain chronic diseases (Table 4), which could be helpful for establishing dietary guidelines for human beings to maintain good health, and for the utilization of tea as a raw material to develop functional beverages, nutraceuticals, and pharmaceuticals.

\section{Potential Safety Issues}

Food safety has attracted increasing attention due to its importance to human health. The safety issues of tea and its bioactive components should never be ignored despite its prominent health functions. There are several suspicions regarding the safety of tea, such as pollution by heavy metals, pesticide residues, and mycotoxin production during fermentation and storage, and the toxicity of high doses of its bioactive components $[27,209-211]$ The potential safety issues of tea are summarized in Table 5. 
Table 2. Effects of tea and its components on microbes in vitro.

\begin{tabular}{|c|c|c|c|c|}
\hline Ingredients & Dosages & Microbes & Effects & References \\
\hline $\begin{array}{l}\text { Polyphenols from green, oolong, and } \\
\text { black teas }\end{array}$ & $1 \%(w / v)$ in medium & Bacterium & $\begin{array}{l}\text { Modulate intestinal flora, induce the proliferation of Bifidobacterium spp., and } \\
\text { Lactobacillus/Enterococcus spp., and inhibit Bacteroides-Prevotella and } \\
\text { Clostridium histolyticum. }\end{array}$ & [61] \\
\hline Green tea & MIC: $400 \mu \mathrm{g} / \mathrm{mL}$ & Bacterium & $\begin{array}{c}\text { Anti-bacterial activities against Propionibacterium acnes, P. granulosum, Staphylococcus } \\
\text { aureus, and S. epidermidis }\end{array}$ & [206] \\
\hline Green and black tea blend & MIC and MBC: $12.5 \mathrm{mg} / \mathrm{mL}$ & Bacterium & Anti-bacterial and bactericidal activities against Streptococcus mutans. & [203] \\
\hline Green tea extract & & Bacterium & Bactericidal activity against Streptococcus mutans. & [205] \\
\hline 23 tea extractions & MIC: $0.078-0.156 \mathrm{mg} / \mathrm{mL}$ & Fungus & Anti-fungal activities against Candida glabrata, C. albicans and C. parapsilosis. & [204] \\
\hline $\begin{array}{l}\text { Tea polyphenols, tea saponins and } \\
\text { their combination }\end{array}$ & $\mathrm{IC}_{50}: 1.66-2.92 \mathrm{mg} / \mathrm{mL}$ & Fungus & $\begin{array}{l}\text { Inhibit the growth of Rhizopus stolonifer by inducing } \mathrm{H}_{2} \mathrm{O}_{2} \text { production, leading to cell } \\
\text { membrane oxidative damage and intracellular constituent leakage. }\end{array}$ & [56] \\
\hline $\begin{array}{l}\text { Tea gallic acid, GCG, Teavigo ( }>90 \% \\
\text { EGCG), and theaflavin-3,3'- digallate }\end{array}$ & $\begin{array}{l}15,30,60,120 \mu \mathrm{mol} / \mathrm{L} \text { gallic acid and } \\
2.5,5,10,20,40 \mu \mathrm{mol} / \mathrm{L} \text { GCG, Teavigo, } \\
\text { and theaflavin- } 3,3^{\prime} \text {-digallate }\end{array}$ & Fungus & Inhibit germination and outgrowth of Bacillus subtilis spores. & [207] \\
\hline Green tea extract & $0.5,5$ and $10 \mathrm{mg} / \mathrm{mL}$ & Virus & Inhibit enteric viruses including murine norovirus and hepatitis A virus. & [208] \\
\hline Pu-erh tea ellagic acid & $\mathrm{IC}_{50}: 6 \mu \mathrm{mol} / \mathrm{L}$ & Virus & Anti-viral activities against human influenza virus A/Puerto Rico/8/34. & [34] \\
\hline
\end{tabular}

Notes: EGCG, epigellocatechin gallate; GCG, gellocatechin gallate; MBC, minimum bactericidal concentration; MIC, minimum inhibitory concentration; $\mathrm{CC}_{50}, 50 \%$ inhibitory concentration.

Table 3. Various in vivo effects of tea and its components.

\begin{tabular}{|c|c|c|c|c|c|}
\hline Ingredients & Dosages & Subjects & Categories & Effects and Molecular Mechanisms & References \\
\hline Green tea extract & $1 \mathrm{~mL} / 100 \mathrm{~g} \mathrm{BW}, 1 \mathrm{w}$ & Rats & Reno-protection & Protect against proline-induced oxidative damage in the kidney. & [178] \\
\hline Green tea extract & $300 \mathrm{mg} / \mathrm{kg} \mathrm{BW}, 15 \mathrm{~d}$ & Rats & Reno-protection & $\begin{array}{l}\text { Ameliorate nephrotoxicity induced by gentamicin, by decreasing } \\
\text { oxidative stress and lipid peroxidation in the kidney. }\end{array}$ & [180] \\
\hline $\begin{array}{l}\text { Polyphenols from } \\
\text { green tea }\end{array}$ & 20 or $50 \mathrm{mg} / \mathrm{kg}$ BW, $60 \mathrm{~d}$ & Wistar rats & Reno-protection & $\begin{array}{l}\text { Protect against } \mathrm{Pb} \text {-induced renal dysfunction and intoxication, by } \\
\text { reducing Pb concentration and accumulation in kidney, } \\
\text { suppressing apoptosis, scavenging ROS, inhibiting ROS-mediated } \\
\text { ERK/JNK/p38 pathway and downstream cytokines. }\end{array}$ & [181] \\
\hline $\begin{array}{l}\text { Polyphenols from } \\
\text { green tea }\end{array}$ & $200 \mathrm{mg} / \mathrm{kg} \mathrm{BW}, 18 \mathrm{~d}$ & Wistar rats & Reno-protection & $\begin{array}{l}\text { Ameliorate high-fat diet-induced kidney injury, by regulating } \\
\text { autophagy-lysosome related proteins (LC3-II, Beclin-1, p62, } \\
\text { cathepsin B, cathepsin D, and LAMP-1) and elevating } \\
\text { AMPK phosphorylation. }\end{array}$ & [182] \\
\hline EGCG from green tea & $50 \mathrm{mg} / \mathrm{kg} \mathrm{BW}$, once & SD rats & Reno-protection & $\begin{array}{l}\text { Alleviate renal ischemia-reperfusion injury, by suppressing } \\
\text { inflammation and cell apoptosis via regulating expression of } \\
\text { TNF- } \alpha \text {, IL-1 } \beta \text {, IL-6, Bax, and caspase- }-3 \text {. }\end{array}$ & [179] \\
\hline EGCG from green tea & $50 \mathrm{mg} / \mathrm{kg} \mathrm{BW}, 3 \mathrm{w}$ & $129 / \mathrm{svJ}$ mice & Reno-protection & $\begin{array}{c}\text { Ameliorate crescentic glomerulonephritis, by restoring Nrf2 } \\
\text { activity and PPAR and SIRT1 levels, and decreasing p-Akt, p-JNK, } \\
\text { p-ERK1/2, and p-P38. }\end{array}$ & [183] \\
\hline
\end{tabular}


Table 3. Cont

\begin{tabular}{|c|c|c|c|c|c|}
\hline Ingredients & Dosages & Subjects & Categories & Effects and Molecular Mechanisms & References \\
\hline $\begin{array}{l}\text { Microbial metabolites } \\
\text { of Chinese dark tea }\end{array}$ & $10 \mathrm{mg} / \mathrm{kg}$ BW, $14 \mathrm{w}$ & SAMP8 mice & Neuro-protection & $\begin{array}{l}\text { Protect against age-related neurodegenerative disorders, by } \\
\text { down-regulating the formation of } 4 \text {-HNE and ubiquitinated } \\
\text { protein aggregates and the } A \beta \text { metabolic pathway, increasing } \\
\text { endogenous anti-oxidant capacity, relieving cell hypoxia, and } \\
\text { reducing the rate of neuronal apoptosis. }\end{array}$ & [185] \\
\hline Black tea & $1.5 \%$ in drinking water, $60 \mathrm{~d}$ & Wistar rats & Neuro-protection & $\begin{array}{c}\text { Protect against } \mathrm{AD} \text { induced by } \mathrm{AlCl}_{3} \text {, attenuated cognitive deficits, } \\
\text { by improving beta-amyloid } 1-42 \text {, acetylcholinesterase, TBARS, } \\
\text { GSH, SOD, CAT, GPX, Bax, Bc1-2, cyto c, and caspases-3/8/9 in } \\
\text { hippocampus and cortex. }\end{array}$ & [189] \\
\hline Green tea & $\begin{array}{l}1333 \mathrm{mg} / \mathrm{mL} \text { in drinking water, } \\
8 \mathrm{w}\end{array}$ & Rats & Neuro-protection & $\begin{array}{l}\text { Protect against } \mathrm{AD} \text {, avoided memory deficits, by preventing } \\
\text { oxidative stress and damage in the hippocampus. }\end{array}$ & [187] \\
\hline Green tea & $2 \mathrm{~g} / 2$ pills/d, $2 \mathrm{~m}$ & Patients with AD & Neuro-protection & $\begin{array}{l}\text { The benefit to cognitive function, by enhancing } \\
\text { anti-oxidant system. }\end{array}$ & [184] \\
\hline $\begin{array}{l}\text { Polyphenols form } \\
\text { green tea }\end{array}$ & $2 \mathrm{~g} / \mathrm{L}$ in drinking water, $8 \mathrm{w}$ & C57BL/6J mice & Neuro-protection & $\begin{array}{l}\text { Ameliorate memory impairment, by reversing the relatively } \\
\text { shallow daily oscillations of circadian clock genes transcription and } \\
\text { protein expression in both liver and hypothalamus. }\end{array}$ & [190] \\
\hline GABA from green tea & $0.83,1.67$, or $3.33 \mathrm{~g} / \mathrm{kg} \mathrm{BW}, 15 \mathrm{~d}$ & Mice & Neuro-protection & $\begin{array}{l}\text { Reduce depression, by modulating GABAergic neurotransmission } \\
\text { of cerebral cortex via up-regulating the expression of GABA(A) } \\
\text { receptor } \alpha 1 .\end{array}$ & [188] \\
\hline GABA green tea & 50 and $100 \mathrm{mg} / \mathrm{kg} \mathrm{BW}, 7 \mathrm{~d}$ & Balb/c mice & Neuro-protection & $\begin{array}{l}\text { Reduce depression in post-stroke depressive mice, by reducing } \\
\text { oxidative stress via improving endogenous anti-oxidant system. }\end{array}$ & [186] \\
\hline Pu-erh tea & $0.50,1.00$, or $1.50 \mathrm{~g} / \mathrm{kg} \mathrm{BW}, 14 \mathrm{~d}$ & SD rats & Gastrointestinal-protection & $\begin{array}{l}\text { Ameliorate gastric ulcer, by decreasing the activity of } \\
\text { myeloperoxidase and the concentration of asymmetric arginine in } \\
\text { gastric mucosal homogenate. }\end{array}$ & [194] \\
\hline $\begin{array}{l}\text { Hetero-polysaccharides } \\
\text { from green and } \\
\text { black teas }\end{array}$ & & Wistar rats & Gastrointestinal-protection & $\begin{array}{l}\text { Ameliorate gastric ulcer, by protecting gastric mucosa, reducing } \\
\text { gastric lesions, and maintaining gastric mucus. }\end{array}$ & [192] \\
\hline $\begin{array}{l}\text { Polyphenols from } \\
\text { dragon pearl tea }\end{array}$ & 50,100, or $200 \mathrm{mg} / \mathrm{kg} \mathrm{BW}, 4 \mathrm{w}$ & Mice & Gastrointestinal-protection & $\begin{array}{l}\text { Ameliorate gastric ulcer, by improving stomach acidity conditions, } \\
\text { altering serum levels of SOD, GPX, CAT, MDA, and lipid } \\
\text { peroxidation, increasing the mRNA expression levels of epidermal } \\
\text { growth factor, epidermal growth factor receptor, vascular } \\
\text { endothelial growth factor, and vascular endothelial growth factor } \\
\text { receptor 1, and reducing gastrin expression levels. }\end{array}$ & [195] \\
\hline Fuzhuan brick-tea & $200 \mathrm{mg} / \mathrm{kg} \mathrm{BW}, 8 \mathrm{w}$ & Rats & Gastrointestinal-protection & $\begin{array}{l}\text { Improve the intestinal function of high-fat diet-fed to rats, by } \\
\text { increasing two Lactobacillus spp in intestinal microbiota. }\end{array}$ & [191] \\
\hline
\end{tabular}


Table 3. Cont

\begin{tabular}{|c|c|c|c|c|c|}
\hline Ingredients & Dosages & Subjects & Categories & Effects and Molecular Mechanisms & References \\
\hline Fuzhuan brick-tea & 1,10 , or $20 \mathrm{~g} / \mathrm{kg} \mathrm{BW}, 10 \mathrm{~d}$ & Kunming mice & Gastrointestinal-protection & $\begin{array}{l}\text { Regulate colonic microbiota, increased species diversity in } \\
\text { Lactobacillus, Bacteroides, and Clostridium cluster IV. }\end{array}$ & [193] \\
\hline $\begin{array}{l}\text { Ripped Pu-erh } \\
\text { tea extract }\end{array}$ & $\begin{array}{c}0.1 \%, 0.2 \%, \text { or } 0.4 \% \text { in tap water, } \\
8 \mathrm{w}\end{array}$ & Male C57BL/6N mice & & $\begin{array}{l}\text { Decrease weight gain, fat accumulation, adipose inflammation, and } \\
\text { metabolic endotoxemia while improving the intestinal barrier } \\
\text { integrity, by modulating gut microbiota composition (decreasing } \\
\text { the Firmicutes/Bacteroidetes ratio). }\end{array}$ & [196] \\
\hline $\begin{array}{l}\text { Water extracts of } \\
\text { green, oolong, and } \\
\text { black teas }\end{array}$ & $1 \%$ in drinking water, $28 \mathrm{w}$ & C57BL/6J mice & Gut microbiota modulation & $\begin{array}{c}\text { Reduce gain in weight, hepatic lipid, and white adipose tissue } \\
\text { weight and plasma level of LPS, increase production of short-chain } \\
\text { fatty acids, by regulating gut microbiota composition (decreasing } \\
\text { the relative abundance of family Rikenellaceae and } \\
\text { Desulfovibrionaceae and changing the abundance of key operational } \\
\text { taxonomic units including Alistipes, Rikenella, Ruminiclostridium, } \\
\text { and Acetatifactor). }\end{array}$ & [197] \\
\hline $\begin{array}{l}\text { Polyphenols from } \\
\text { green tea }\end{array}$ & $0.1 \%$ in diet, $8 \mathrm{w}$ & C57BL/6J mice & Gut microbiota modulation & $\begin{array}{l}\text { Ameliorate the obesity-induced gut dysbiosis, decrease the } \\
\text { Firmicutes/Bacteroidetes ratio. }\end{array}$ & [198] \\
\hline $\begin{array}{l}\text { Extract of Fuzhuan } \\
\text { brick-tea }\end{array}$ & $400 \mathrm{mg} / \mathrm{kg} \mathrm{BW}, 8 \mathrm{w}$ & C57BL/6J mice & Gut microbiota modulation & $\begin{array}{c}\text { Improve oxidative injury, inflammation, lipid metabolism, and } \\
\text { obesity, by enhancing the diversity of gut microbiota, reducing the } \\
\text { Firmicutes/Bacteroidetes ratio, and enhancing the relative abundance } \\
\text { of Bifidobacteriaceae. }\end{array}$ & [199] \\
\hline $\begin{array}{l}\text { Polysaccharides from } \\
\text { Fuzhuan brick tea }\end{array}$ & 200,400 , or $800 \mathrm{mg} / \mathrm{kg} \mathrm{BW}, 8 \mathrm{w}$ & C57BL/6 mice & Gut microbiota modulation & $\begin{array}{l}\text { Increase phylogenetic diversity of gut microbiota, restore the } \\
\text { HFD-induced increases in relative abundances of } \\
\text { Erysipelotrichaceae, Coriobacteriaceae, and Streptococcaceae. }\end{array}$ & [201] \\
\hline $\begin{array}{l}\text { Polyphenols from } \\
\text { green tea }\end{array}$ & $\begin{array}{l}0.5 \% \text { and } 1.5 \% \text { in drinking water, } \\
3 \text { or } 6 \mathrm{~m}\end{array}$ & SD rats & Gut microbiota modulation & $\begin{array}{l}\text { Modify gut-microbiota dependent metabolisms of energy, bile } \\
\text { constituents, and micronutrients }\end{array}$ & [200] \\
\hline Tea polyphenols & 100,200 , or $400 \mathrm{mg} / \mathrm{kg} \mathrm{BW}, 12 \mathrm{w}$ & C57BL/6 mice & Gut microbiota modulation & $\begin{array}{l}\text { Ameliorate hyperlipidemia, improve the expression levels of } \\
\text { hepatic lipid metabolism genes, and modulate gut microbiota, by } \\
\text { modulating intestinal redox state. }\end{array}$ & [202] \\
\hline $\begin{array}{l}\text { Notes: 4-HNE, 4-H } \\
\text { lymphoma 2; CAT } \\
\text { glutathione; HFD, } \\
\text { malonaldehyde; } 1 \\
\text { sirtuin 1; TBARS, }\end{array}$ & $\begin{array}{l}\text { oxynonenal; AD, Alzheimer's } \\
\text { alase; EGCG, epigallocatechin } \\
\text { fat diet; IL, interleukins; JNK, } \\
\text { nuclear factor erythroid 2-rel } \\
\text { parbituric acid reactive substar }\end{array}$ & $\begin{array}{l}\text { se; Akt, protein ki1 } \\
\text { te; ERK, extracell }\end{array}$ & $\begin{array}{l}\text { AMPK, adenosine mon } \\
\text { gnal-regulated kinases; } \\
\text { IMP-1, lysosomal-assoc } \\
\text { ome proliferator-activa } \\
\text { factor } \alpha \text {. }\end{array}$ & $\begin{array}{l}\text { phate-activated protein kinase; Bax, Bcl-2-associated X prot } \\
\text { A, gamma-aminobutyric acid; GPX, glutathione peroxidase } \\
\text { nembrane protein 1; LC3-II, light chain 3-II; LPS, lipopolysa } \\
\text { ceptor; ROS, reactive oxygen species; SOD, superoxide di }\end{array}$ & $\begin{array}{l}1-2, \text { B-cell } \\
\text { I, reduced } \\
\text { ide; MDA, } \\
\text { se; SIRT1, }\end{array}$ \\
\hline
\end{tabular}


Table 4. Health functions of tea in clinical trials.

\begin{tabular}{|c|c|c|c|c|c|}
\hline Subjects & Ingredients & Dosages & Health Functions & Mechanisms & References \\
\hline 60 male sprinters & Green tea extract & $\begin{array}{l}2 \text { capsules } \times \text { times } / \mathrm{d}, 2 \times 4 \mathrm{w} \\
\text { with a } 4 \text {-week washout period }\end{array}$ & Antioxidation & $\begin{array}{l}\text { Prevent oxidative stress, by increasing total antioxidant } \\
\text { capacity and decreasing MDA level of blood plasma. }\end{array}$ & [85] \\
\hline $\begin{array}{c}\quad 60 \text { mildly } \\
\text { hyper-cholesterolemic subjects }\end{array}$ & $\begin{array}{l}\text { Catechin- enriched green and } \\
\text { oolong tea }\end{array}$ & $2 \times 300 \mathrm{~mL} / \mathrm{d}, 12 \mathrm{w}$ & Antioxidation & $\begin{array}{l}\text { Improve GSH, SOD, CAT, GPx, and GR, and decrease } \\
\text { lipid peroxidation. }\end{array}$ & [87] \\
\hline 32 participants & $\begin{array}{l}\text { Benifuuki and Yabukita green } \\
\text { tea }\end{array}$ & $3 \mathrm{cups} / \mathrm{d}, 2 \mathrm{w}$ & Antioxidation & $\begin{array}{l}\text { Protect against cutaneous oxidative stress, by increasing the } \\
\text { radical scavenging activity of the skin. }\end{array}$ & [86] \\
\hline 68 SLE patients & Green tea extract & $1000 \mathrm{mg} / 2$ capsules/d, $12 \mathrm{w}$ & Anti-inflammation & $\begin{array}{l}\text { Improve the SLE disease as well as the corresponding vitality } \\
\text { and general health. }\end{array}$ & [94] \\
\hline 45 male soldiers & Green tea & $12 \mathrm{~g}$ tea leaves $/ \mathrm{d}$ & Anti-inflammation & $\begin{array}{l}\text { Decrease plasma levels of IL-6 and NF-kB in soldiers with } \\
\text { sleep deprivation. }\end{array}$ & [95] \\
\hline 9 well-trained male cyclists & Green tea and carbohydrate & Acute ingestion & Anti-inflammation & $\begin{array}{l}\text { Did not evidently improve inflammatory biomarkers during } \\
\text { sprint cycling in athletes in comparison to carbohydrates. }\end{array}$ & [96] \\
\hline 16 tobacco smokers & Green tea & $5 \times 1 \mathrm{cup} / \mathrm{d}, 4 \mathrm{w}$ & Anticancer & $\begin{array}{c}\text { Reduce the risk of oral carcinogenesis, by modulating } \\
\text { oral bacteria. }\end{array}$ & [110] \\
\hline $\begin{array}{l}70 \text { Algerian prostate cancer } \\
\text { patients and } 120 \text { age-matched } \\
\text { healthy subjects }\end{array}$ & Green tea & $5 \mathrm{cups} / 2 \mathrm{~g}$ tea leaves $/ \mathrm{d}, 6 \mathrm{~m}$ & Anticancer & Prevent prostate cancer initiation or delay its progression. & [111] \\
\hline $\begin{array}{l}60 \text { high-grade prostate } \\
\text { intraepithelial } \\
\text { neoplasia patients }\end{array}$ & Green tea catechins & $600 \mathrm{mg} / \mathrm{d}, 6$ and $12 \mathrm{~m}$ & Anticancer & $\begin{array}{c}\text { Show a non-significant improvement in lower urinary tract } \\
\text { symptoms and a better quality of life with very limited } \\
\text { adverse effects. }\end{array}$ & [112] \\
\hline $\begin{array}{l}20 \text { obese } \\
\text { prehypertensive women }\end{array}$ & Green tea extract & $500 \mathrm{mg} / 3$ capsules $/ \mathrm{d}, 4 \mathrm{w}$ & Cardiovascular-protection & Reduce blood pressure. & [135] \\
\hline 20 healthy participants & Black tea & $200 \mathrm{~mL} / \mathrm{d}, 1 \mathrm{w}$ & Cardiovascular-protection & $\begin{array}{c}\text { Enhance the cutaneous vascular response to gradual local } \\
\text { heating to } 42^{\circ} \mathrm{C} \text {, by activating endothelium-derived chemical } \\
\text { mediators like NO. }\end{array}$ & [136] \\
\hline 19 hypertensive patients & Black tea & $\begin{array}{l}\text { With } 150 \mathrm{mg} \text { polyphenols, } \\
\text { twice/d, } 8 \mathrm{~d}\end{array}$ & Cardiovascular-protection & $\begin{array}{l}\text { Protect blood vessels, by augmenting the amount of circulating } \\
\text { angiogenic cells and blocking endothelial dysfunction. }\end{array}$ & [137] \\
\hline 30 healthy male smokers & Green tea catechins & $580 \mathrm{mg} / \mathrm{d}, 2 \mathrm{w}$ & Cardiovascular-protection & $\begin{array}{l}\text { Improve human forearm endothelial dysfunction, and } \\
\text { anti-atherosclerosis. }\end{array}$ & [138] \\
\hline 50 healthy men & Green tea & equivalent to $200 \mathrm{mg}$ EGCG/d & Cardiovascular-protection & $\begin{array}{l}\text { Improve the endothelial function in humans in terms of } \\
\text { flow-mediated dilation. }\end{array}$ & [139] \\
\hline 936 postmenopausal women & Green tea extracts & $\begin{array}{l}1315 \mathrm{mg} \text { catechins/4 capsules/d, } \\
12 \mathrm{~m}\end{array}$ & Cardiovascular-protection & $\begin{array}{l}\text { Reduce blood TC and LDL-C levels, particularly in subjects } \\
\text { with increased baseline TC level. }\end{array}$ & [141] \\
\hline $\begin{array}{l}99 \text { mild } \\
\text { hyper-cholesterolemia subjects }\end{array}$ & Functional black tea & $\begin{array}{l}\text { with } 2 \mathrm{~g} \text { phytosterols, } \\
\text { once/d, } 4 \mathrm{w}\end{array}$ & Cardiovascular-protection & $\begin{array}{l}\text { Reduce the TC, LDL-C, and apolipoprotein B levels, as well as } \\
\text { oxidative stress index, increase adiponectin and } \\
\text { tissue-plasminogen activator, and improve total } \\
\text { antioxidant status. }\end{array}$ & [142] \\
\hline
\end{tabular}


Table 4. Cont.

\begin{tabular}{|c|c|c|c|c|c|}
\hline Subjects & Ingredients & Dosages & Health Functions & Mechanisms & References \\
\hline $\begin{array}{l}57 \text { borderline } \\
\text { hypercholesterolemic } \\
\text { individuals }\end{array}$ & Black tea & 5 cups $/ \mathrm{d}, 4 \mathrm{w}$ & Cardiovascular-protection & Show no significant alteration on the lipid profile. & [143] \\
\hline 30 T2DM patients & Black tea & $\begin{array}{l}1 \text { or } 3 \text { cups }(200 \text { or } 600 \mathrm{~mL}) / \mathrm{d} \\
12 \mathrm{w}\end{array}$ & Anti-diabetes & $\begin{array}{l}\text { Reduce HbA1c level and help to decrease the risk of suffering } \\
\text { from TD2M. }\end{array}$ & [150] \\
\hline 15 healthy subjects & Green tea & $\begin{array}{l}400 \mathrm{~mL} / \text { visit, } 5 \text { visits with a } \\
\text { two-week washout period }\end{array}$ & Anti-diabetes & $\begin{array}{c}\text { Suppress postprandial plasma glucose and } \\
\text { insulin concentration. }\end{array}$ & [152] \\
\hline 35 diabetic subjects & Green tea extract & $1120 \mathrm{mg} / \mathrm{d}, 10$ and $20 \mathrm{w}$ & Anti-diabetes & $\begin{array}{l}\text { Improve glycemic control and prevent osteoporosis in } \\
\text { diabetic patients }\end{array}$ & [153] \\
\hline 102 women with central obesity & Green tea extracts & $856.8 \mathrm{mg} / \mathrm{d}, 12 \mathrm{w}$ & Anti-obesity & $\begin{array}{l}\text { Reduce body weight, waist circumference, and plasma TC and } \\
\text { LDL levels, probably by inhibiting ghrelin secretion and } \\
\text { increasing adiponectin levels. }\end{array}$ & [161] \\
\hline 50 overweight women & Mixture of extracts & $\begin{array}{l}125 \mathrm{mg} \text { green tea, } 25 \mathrm{mg} \\
\text { capsaicin, and } 50 \mathrm{mg} \text { ginger } \\
\text { extracts } / \mathrm{d}, 8 \mathrm{w}\end{array}$ & Anti-obesity & $\begin{array}{l}\text { Reduce the weight, BMI, plasma GSH level, and insulin } \\
\text { metabolism markers. }\end{array}$ & [162] \\
\hline $\begin{array}{l}30 \text { non-athlete } \\
\text { overweight females }\end{array}$ & green tea & $\begin{array}{l}500 \mathrm{mg} / 3 \text { tablets/d with high- } \\
\text { intensity interval training, } 10 \mathrm{w}\end{array}$ & Anti-obesity & $\begin{array}{l}\text { Reduce body weight, BMI, and the undesirable consequence of } \\
\text { overweight, by augmenting the levels of SIRT-1 and PPAR } \gamma \\
\text { co-activator 1- } \alpha \text {. }\end{array}$ & [164] \\
\hline 48 overweight males & Green tea extracts & $\begin{array}{l}250 \mathrm{mg} / 3 \text { capsules/d, with } \\
\text { interval sprinting exercise, } 12 \mathrm{w}\end{array}$ & Anti-obesity & $\begin{array}{l}\text { Decrease body and abdominal fat, and increase total lean mass } \\
\text { in overweight males }\end{array}$ & [165] \\
\hline 80 participants with NAFLD & Green tea extract & $500 \mathrm{mg} / \mathrm{d}, 90 \mathrm{~d}$ & Hepato- protection & $\begin{array}{c}\text { Decrease the levels of liver enzymes including ALT, AST, } \\
\text { and ALP }\end{array}$ & [177] \\
\hline $\begin{array}{l}\quad 60 \text { mildly } \\
\text { hypercholesterolemic subjects }\end{array}$ & $\begin{array}{l}\text { Catechin- enriched green and } \\
\text { oolong teas }\end{array}$ & $2 \times 300 \mathrm{~mL} / \mathrm{d}, 12 \mathrm{w}$ & Hepato- protection & $\begin{array}{l}\text { Decrease body weight, BMI, fat, lipid peroxidation, and lipid } \\
\text { profiles (TG, TC, LDL-C, and HDL-C), and improve GSH, SOD, } \\
\text { CAT, GPX, and GR in the liver. }\end{array}$ & [87] \\
\hline
\end{tabular}

Notes: ALP, alkaline phosphatase; ALT, alanine aminotransferase; AST, aspartate transaminase; BMI, body mass index; CAT, catalase; GPx, glutathione peroxidase; GR, glutathione reductase; GSH, reduced glutathione; HbA1c, glycated hemoglobin A1C; HDL-C, high-density lipoprotein-cholesterol; IL, interleukins; LDL-C, low-density lipoprotein-cholesterol; MDA, malonaldehyde; NF-kB, nuclear factor- $\mathrm{kB}$; PPAR $\gamma$, peroxisome proliferator-activated receptor $\gamma$; SIRT1, sirtuin 1; SLE, systemic lupus erythematosus; SOD, superoxide dismutase; T2DM, type II diabetes mellitus; TC, total cholesterol; TG, triglyceride. 
Table 5. Potential safety issues of tea.

\begin{tabular}{|c|c|c|c|c|c|}
\hline Samples & Location & Safety Categories & Specific Safety Items & Remarks & References \\
\hline 15 teas & Ghana & & $\mathrm{Fe}, \mathrm{Cu}, \mathrm{Zn}, \mathrm{Pb}, \mathrm{As}$, and $\mathrm{Cd}$ & Below the maximum permissible limits by WHO and USP. & [212] \\
\hline 26 teas & Guizhou, China & Heavy metal & $\mathrm{Pb}, \mathrm{Cu}, \mathrm{As}, \mathrm{Hg}, \mathrm{Cd}$, and $\mathrm{Cr}$ & Below the standard limit values in China. & [213] \\
\hline 26 green teas & Jiangxi, China & & $\mathrm{Cd}, \mathrm{Cr}, \mathrm{Pb}$, and $\mathrm{Cu}$ & $\begin{array}{l}\mathrm{Cu} \text { content }(31.48 \mathrm{mg} / \mathrm{kg} \text { ) in one sample exceeded the } \\
\text { maximum allowable levels }(30 \mathrm{mg} / \mathrm{kg} \text { ) for tea. }\end{array}$ & {$[214]$} \\
\hline $100 \mathrm{Pu}$-erh teas & Yunnan, China & & 74 pesticides & $\begin{array}{l}11 \text { pesticides were detected, below the Chinese maximum } \\
\text { residual levels. }\end{array}$ & [215] \\
\hline 6 teas & Different regions of China & Pesticide & $\begin{array}{l}\text { Lindane, Parathion-Methyl, } \\
\text { Methidathion, Fenitrothion, Fenthion, } \\
\text { Fenpropathrin, Endosulfan sulfate, } \\
\alpha \text {-Endosulfan, } \beta \text {-Endosulfan, P,P'-DDE, } \\
\text { O,P'-DDT, P,P'-DDD, P,P'-DDT, } \\
\text { Bifenthrin, Permethrin }\end{array}$ & Below the MRLs by European Union. & [216] \\
\hline 223 teas & $\begin{array}{l}\text { Yunnan, Zhejiang, and } \\
\text { Fujian, China }\end{array}$ & & 32 pesticides & $\begin{array}{l}\text { Residue levels in } 39 \text { samples exceeded the MRLs by } \\
\text { European Union. }\end{array}$ & [217] \\
\hline 24 teas & Beijing, China & & 15 classes of pesticides & $\begin{array}{l}\text { Chlorpyrifos }(145.1 \mu \mathrm{g} / \mathrm{kg}) \text { and } \alpha-\mathrm{HCH}(22.2 \mu \mathrm{g} / \mathrm{kg}) \text { in } \\
\text { green tea exceeded the European Union MRLs }(100 \text { and } 20 \\
\mu \mathrm{g} / \mathrm{kg} \text {, respectively). }\end{array}$ & [218] \\
\hline 8 teas & Beijing, China & & $\begin{array}{l}\text { Methomyl, Dimethoate, Propoxur, } \\
\text { Carbaryl, Pirimicarb, Malathion, } \\
\text { Fenitrothion, Kresoxim-methyl, } \\
\text { Bifenthrin, Chlorpyrifos, Fenpropathrin, } \\
\text { Lambda-cyhalothrin, Cypermethrin, } \\
\text { Deltamethrin, Fenvalerate, Carbosulfan }\end{array}$ & $\begin{array}{l}\text { Methomyl }(197.45 \mathrm{ng} / \mathrm{g} v s .100 \mathrm{ng} / \mathrm{g} \text { ) in black tea exceeded } \\
\text { the MRLs by European Union. }\end{array}$ & [219] \\
\hline 18 teas & Almería, Spain & Mycotoxin & Aflatoxins & $\begin{array}{l}\text { The aflatoxin B1 }(5.4 \mathrm{mu} \mathrm{g} / \mathrm{kg}) \text { was found in one of the } \\
\text { green tea samples. }\end{array}$ & [220] \\
\hline $36 \mathrm{Pu}$-erh teas & Yunnan, China & & Aflatoxins, fumonisins, and ochratoxins & Ochratoxin A was detected in 4 of 36 teas $(11.1 \%)$. & [221] \\
\hline Green tea extract & & & Mutagenic and genotoxic toxicity & No targeted effects were observed. & [222] \\
\hline Black tea extract & & Toxicity & Acute and sub-chronic toxicity & No targeted effects were observed. & [223] \\
\hline Green tea extract & & & Gastrointestinal symptom & $\begin{array}{l}6.7 \% \text { of the participants experienced alanine } \\
\text { aminotransferase elevations, with } 1.3 \% \text { experiencing } \\
\text { alanine aminotransferase-related serious adverse events. }\end{array}$ & [224] \\
\hline
\end{tabular}

Notes: DDD, dichlorodiphenyldichloroethane; DDE, dichlorodiphenyldichloroethylene; DDT, dichlorodiphenyltrichloroethane; HCH, hexachlorocyclohexane; MRLs, maximum residue levels; USP, United States Pharmacopeia; WHO, world health organization. 
Many elements have been detected in tea, including plumbum $(\mathrm{Pb})$, cadmium $(\mathrm{Cd})$, copper $(\mathrm{Cu})$, cobalt $(\mathrm{Co})$, chromium $(\mathrm{Cr})$, nickel $(\mathrm{Ni})$, manganese $(\mathrm{Mn})$, aluminum $(\mathrm{Al})$, arsenic $(\mathrm{As})$, and fluorine $(\mathrm{F})[212,214,225]$. Some elements, such as $\mathrm{Pb}$ and $\mathrm{Cd}$, are toxic, and others, such as $\mathrm{Cu}$ and F, are essential elements, but they can be harmful at high levels. Fortunately, the contents of these elements in tea were generally below the maximum permissible limits stipulated by the World Health Organization (WHO) and the United States Pharmacopeia (USP) [212]. In addition, both the target hazard quotient (THQ) and hazard index (HI) levels regarding these elements in certain teas were far below 1, indicating that tea consumption would not increase health risks [214,225]. Besides, the THQ and HI values would decrease as the infusion time increased, so it was suggested to discard the first tea infusion and consume the later ones [214]. In addition, some elements might be accumulated in tea during plantation, and the most strongly accumulated ones are $\mathrm{Mn}, \mathrm{Al}$, and $\mathrm{F}$, which could induce poisoning symptoms, cognitive dysfunction, fluorosis of bone, and other adverse effects in humans $[213,226,227]$. Environmental and plant factors, such as the soil condition, variety, season, and maturity, might influence the contents and distribution of certain elements in tea. Thus, it is important to monitor these factors to assure that tea products do not contain excessive levels of heavy metals [226].

Excessive levels of pesticide residues, such as organophosphorus chemicals, organochlorines, carbamates, pyrethroids, herbicides, and neonicotinoids, are a serious safety issue that has been monitored for many decades and aroused increasing attention [216,219,228,229]. Specifically, chlorpyrifos, bifenthrin, lambda-cyhalothrin, cypermethrin, imidacloprid, and acetamiprid were frequently detected pesticides in tea [215,218]. Despite of the fact that the detection rates of pesticides in tea were relatively high, most of the investigated pesticides were below the Chinese and European Union maximum residue levels (MRLs) [25,215]. However, in one study, 39 out of 233 tested tea samples were found to exceed European Union MRLs, and bifenthrin had the highest detection rate [217]. On the other hand, the transfer rates of pesticides from tea leaves into the infusion should be taken into consideration when conducting risk assessments of pesticides in teas, since it could be affected by the solubility and polarity of pesticides, the temperature of the water, and brewing time [230-232]. In one study investigating 810 Chinese teas, the THQ values of organophosphorus pesticides from tea consumption were below 0.02 , so the exposure of tea drinking-induced organophosphorus pesticide was unlikely to induce adverse health problems in humans [233].

Fermentation by a microbial consortium composed of bacteria, molds, and yeasts is probably the most important process in manufacturing some kinds of teas, in which a series of biochemical reactions occur, and the components are greatly transformed $[7,234,235]$. Some harmful fungi might bring potential safety hazards to the production of fermented teas during the fermentation stage as well as the storage period [220]. Aflatoxins, fumonisins, and ochratoxin A could be found in some tea samples, among which aflatoxin B1, the most toxic aflatoxin, could induce extremely serious hepatotoxicity, and it is not easy to remove in normal ways like flushing with water or heating at high temperature, even up to $200{ }^{\circ} \mathrm{C}$ [221]. Thus, it is important to monitor the fermentation process of tea so as to avoid the production of toxic metabolites.

Consumption of tea has been reported with few adverse events [127,148,236]. Tumorigenic, mutagenic, teratogenic, and sub-chronic toxicity of tea-related ingredients have not been observed in animal experiments and human studies, and the no-observed-adverse-effect level (NOAEL), observed safety level, and tolerable upper intake level were far from the functional doses [26,222,223,237]. However, some compounds contained in tea has been recognized as anti-nutritive factors. For example, tea tannins and polyphenols may inhibit digestive enzymes, including trypsin, lipase, amylase, and glucosidase that are related to digestion of protein, lipid, and carbohydrate, resulting in the decreased availability of these nutrients, which may do harm to malnutrition persons though benefit obesity or diabetic patients [238-242]. Excessive tea drinking may interfere with iron absorption and subsequently lead to iron deficiency anemia [243-245]. Anti-thiamine component in tea may destroy the bioactivity of thiamine, which cause neurological symptoms consisting of both peripheral and central 
nervous system dysfunction [246]. In addition, consumption of a high dose of tea extract/component (approximately up to $800 \mathrm{mg}$ tea polyphenols) might cause mild acute adverse effects. High intake of caffeine (more than $200 \mathrm{mg} / \mathrm{d}$ ) accompanied by tea consumption could cause, at least in sensitive peoples, short-term stimulation of the nervous system, insomnia, anxiety, palpitations, tremor, and increased blood pressure [247]. Some other harmful effect has also been reported to correlated with tea consumption, such as acute liver damage and gastrointestinal disturbances like nausea and stomach injuries, with the latter more likely to occur when the tea is consumed on an empty stomach instead of a full stomach $[28,224]$. Nevertheless, as demonstrated previously, consuming tea on an empty stomach can improve its bioavailability and consequently enhance its biological efficacy [77]. On the other hand, pretreatment with green tea EGCG may reduce the bioavailability as well as the hepato-toxic effect of subsequent oral bolus doses of EGCG [79]. Based on this discrepancy, considerable attention should be paid to keeping the balance between improving the bioavailability and bioactivity, as well as preventing the adverse effects of natural phytochemicals when investigating their health functions and safety and applying them as functional foods and pharmaceuticals in the future.

To sum up, tea is generally safe for consumption with very rare adverse effects. Rigorous regulations are essential to limit the toxic factors in tea products, including heavy metals, pesticide residues, and mycotoxins from plantation, manufacture, and storage.

\section{Conclusions}

In conclusion, polyphenols, polysaccharides, saponins, pigments, purine alkaloids, and free amino acids in tea can be the major bioactive components that contribute to its diverse health functions. Generally, the bioavailability of tea phytochemicals is relatively low, and some technologies, like modification technology, capsule technology, and nanotechnology, can improve their bioavailability, resulting in the increased bioactivities. The antioxidant, anti-inflammatory, immuno-regulatory, anticancer, cardiovascular-protective, anti-diabetic, anti-obesity, and hepato-protective effects have been widely demonstrated by in vitro, in vivo, and human studies, with various mechanisms of actions. Tea brewing and tea-based products are generally considered safe to consumers, as harmful impacts on animals and human have seldom been reported. Although heavy metals, pesticide residues, and mycotoxins could be detected in certain samples of tea, they are usually below the MRLs. Therefore, tea consumption can be recommended to the public for chronic disease prevention and treatment. In addition, tea can be processed into beverages, functional foods, and pharmaceuticals. In the future, the bioavailability of tea phytochemicals should be intensively investigated, and more technologies should be developed to improve their bioavailability. Underlying mechanisms of the health functions of tea, especially the molecular targets, need to be further clarified. In addition, more well-designed clinical trials are necessary to further verify its health functions. Besides, the synergetic effects of tea and its purified bioactive components with other food bioactive ingredients are worth further study to promote its health functions. Last but not least, more attention should also be paid to the safety of tea, such as contamination by heavy metals, pesticides, and mycotoxins, as well as the potential adverse impact of high doses of tea bioactive components. Overall, tea is a promising dietary component, and its consumption shows many health functions.

Author Contributions: G.-Y.T., R.-Y.G. and H.-B.L. conceived this paper; G.-Y.T., X.M., C.-N.Z. and Q.L. wrote the manuscript; R.-Y.G., Y.-B.F., S.L., X.-L.W., A.G.A., H.C. and H.-B.L. revised the manuscript. The final version was approved by all authors.

Funding: This work was supported by the National Key R\&D Program of China (2018YFC1604400); Shanghai Basic and Key Program (No. 18JC1410800); Technology Innovation Program of Chinese Academy of Agricultural Sciences (ASTIP).

Conflicts of Interest: The authors declare no conflict of interest. 


\section{References}

1. Guo, Y.J.; Sun, L.Q.; Yu, B.Y.; Qi, J. An integrated antioxidant activity fingerprint for commercial teas based on their capacities to scavenge reactive oxygen species. Food Chem. 2017, 237, 645-653. [CrossRef]

2. Islam, S.N.; Farooq, S.; Sehgal, A. Effect of consecutive steeping on antioxidant potential of green, oolong and black tea. Int. J. Food Sci. Technol. 2018, 53, 182-187. [CrossRef]

3. Kujawska, M.; Ewertowska, M.; Ignatowicz, E.; Adamska, T.; Szaefer, H.; Gramza-Michalowska, A.; Korczak, J.; Jodynis-Liebert, J. Evaluation of safety and antioxidant activity of yellow tea (Camellia sinensis) extract for application in food. J. Med. Food 2016, 19, 330-336. [CrossRef]

4. Lv, H.P.; Zhang, Y.; Shi, J.; Lin, Z. Phytochemical profiles and antioxidant activities of Chinese dark teas obtained by different processing technologies. Food Res. Int. 2017, 100, 486-493. [CrossRef]

5. Sanlier, N.; Atik, I.; Atik, A. A minireview of effects of white tea consumption on diseases. Trends Food Sci. Technol. 2018, 82, 82-88. [CrossRef]

6. Hilal, Y.; Engelhardt, U. Characterisation of white tea - Comparison to green and black tea. J. Consum. Prot. Food Saf. 2007, 2, 414-421. [CrossRef]

7. Zheng, W.J.; Wan, X.C.; Bao, G.H. Brick dark tea: A review of the manufacture, chemical constituents and bioconversion of the major chemical components during fermentation. Phytochem. Rev. 2015, 14, 499-523. [CrossRef]

8. Bi, W.; He, C.N.; Ma, Y.Y.; Shen, J.; Zhang, L.H.; Peng, Y.; Xiao, P.G. Investigation of free amino acid, total phenolics, antioxidant activity and purine alkaloids to assess the health properties of non-Camellia tea. Acta Pharm. Sin. B 2016, 6, 170-181. [CrossRef]

9. Guo, L.; Guo, J.C.; Zhu, W.C.; Jiang, X.R. Optimized synchronous extraction process of tea polyphenols and polysaccharides from Huaguoshan Yunwu tea and their antioxidant activities. Food Bioprod. Process. 2016, 100, 303-310. [CrossRef]

10. Pan, H.B.; Wang, F.; Rankin, G.O.; Rojanasakul, Y.; Tu, Y.Y.; Chen, Y.C. Inhibitory effect of black tea pigments, theaflavin-3/3'-gallate against cisplatin-resistant ovarian cancer cells by inducing apoptosis and G1 cell cycle arrest. Int. J. Oncol. 2017, 51, 1508-1520. [CrossRef]

11. Wang, B.; Tu, Y.; Zhao, S.P.; Hao, Y.H.; Liu, J.X.; Liu, F.H.; Xiong, B.H.; Jiang, L.S. Effect of tea saponins on milk performance, milk fatty acids, and immune function in dairy cow. J. Dairy Sci. 2017, 100, 8043-8052. [CrossRef]

12. Tang, G.Y.; Zhao, C.N.; Xu, X.Y.; Gan, R.Y.; Cao, S.Y.; Liu, Q.; Shang, A.; Mao, Q.Q.; Li, H.B. Phytochemical composition and antioxidant capacity of 30 Chinese teas. Antioxidants 2019, 8, 180. [CrossRef]

13. Zhao, C.N.; Tang, G.Y.; Cao, S.Y.; Xu, X.Y.; Gan, R.Y.; Liu, Q.; Mao, Q.Q.; Shang, A.; Li, H.B. Phenolic profiles and antioxidant activities of 30 tea infusions from green, black, oolong, white, yellow and dark teas. Antioxidants 2019, 8, 215. [CrossRef]

14. Di Lorenzo, A.; Curti, V.; Tenore, G.C.; Nabavi, S.M.; Daglia, M. Effects of tea and coffee consumption on cardiovascular diseases and relative risk factors: An update. Curr. Pharm. Design 2017, 23, 2474-2487. [CrossRef]

15. Gan, R.Y.; Li, H.B.; Sui, Z.Q.; Corke, H. Absorption, metabolism, anticancer effect and molecular targets of epigallocatechin gallate (EGCG): An updated review. Crit. Rev. Food Sci. Nutr. 2018, 58, 924-941. [CrossRef]

16. Li, Y.C.; Wang, C.; Huai, Q.J.; Guo, F.C.; Liu, L.Y.; Feng, R.N.; Sun, C.H. Effects of tea or tea extract on metabolic profiles in patients with type 2 diabetes mellitus: A meta-analysis of ten randomized controlled trials. Diabetes Metab. Res. 2016, 32, 2-10. [CrossRef]

17. Ramadan, G.; El-Beih, N.M.; Talaat, R.M.; Abd El-Ghffar, E.A. Anti-inflammatory activity of green versus black tea aqueous extract in a rat model of human rheumatoid arthritis. Int. J. Rheum. Dis. 2017, 20, 203-213. [CrossRef]

18. Santamarina, A.B.; Carvalho-Silva, M.; Gomes, L.M.; Okuda, M.H.; Santana, A.A.; Streck, E.L.; Seelaender, M.; Do Nascimento, C.; Ribeiro, E.B.; Lira, F.S.; et al. Decaffeinated green tea extract rich in epigallocatechin-3-gallate prevents fatty liver disease by increased activities of mitochondrial respiratory chain complexes in diet-induced obesity mice. J. Nutr. Biochem. 2015, 26, 1348-1356. [CrossRef]

19. Suzuki, T.; Pervin, M.; Goto, S.; Isemura, M.; Nakamura, Y. Beneficial effects of tea and the green tea catechin epigallocatechin-3-gallate on obesity. Molecules 2016, 21, 1305. [CrossRef] 
20. Cai, Z.Y.; Li, X.M.; Liang, J.P.; Xiang, L.P.; Wang, K.R.; Shi, Y.L.; Yang, R.; Shi, M.; Ye, J.H.; Lu, J.L.; et al. Bioavailability of tea catechins and its improvement. Molecules 2018, 23, 2346. [CrossRef]

21. Henning, S.M.; Niu, Y.T.; Lee, N.H.; Thames, G.D.; Minutti, R.R.; Wang, H.J.; Go, V.; Heber, D. Bioavailability and antioxidant activity of tea flavanols after consumption of green tea, black tea, or a green tea extract supplement. Am. J. Clin. Nutr. 2004, 80, 1558-1564. [CrossRef]

22. Kulandaivelu, K.; Mandal, A. Improved bioavailability and pharmacokinetics of tea polyphenols by encapsulation into gelatin nanoparticles. IET Nanobiotechnol. 2017, 11, 469-476. [CrossRef]

23. Peng, Y.R.; Meng, Q.L.; Zhou, J.; Chen, B.; Xi, J.J.; Long, P.P.; Zhang, L.; Hou, R.Y. Nanoemulsion delivery system of tea polyphenols enhanced the bioavailability of catechins in rats. Food Chem. 2018, 242, 527-532. [CrossRef]

24. Zou, L.Q.; Liu, W.; Liu, W.L.; Liang, R.H.; Li, T.; Liu, C.M.; Cao, Y.L.; Niu, J.; Liu, Z. Characterization and bioavailability of tea polyphenol nanoliposome prepared by combining an ethanol injection method with dynamic High-Pressure microfluidization. J. Agric. Food Chem. 2014, 62, 934-941. [CrossRef]

25. Cladiere, M.; Delaporte, G.; Le Roux, E.; Camel, V. Multi-class analysis for simultaneous determination of pesticides, mycotoxins, process-induced toxicants and packaging contaminants in tea. Food Chem. 2018, 242, 113-121. [CrossRef]

26. Dekant, W.; Fujii, K.; Shibata, E.; Morita, O.; Shimotoyodome, A. Safety assessment of green tea based beverages and dried green tea extracts as nutritional supplements. Toxicol. Lett. 2017, 277, 104-108. [CrossRef]

27. Gorur, F.K.; Keser, R.; Akcay, N.; Dizman, S.; Okumusoglu, N.T. Radionuclides and heavy metals concentrations in Turkish market tea. Food Control 2011, 22, 2065-2070. [CrossRef]

28. Sarma, D.N.; Barrett, M.L.; Chavez, M.L.; Gardiner, P.; Ko, R.; Mahady, G.B.; Marles, R.J.; Pellicore, L.S.; Giancaspro, G.I.; Dog, T.L. Safety of green tea extracts - a systematic review by the US Pharmacopeia. Drug Saf. 2008, 31, 469-484. [CrossRef]

29. Turkozu, D.; Sanlier, N. L-theanine, unique amino acid of tea, and its metabolism, health effects, and safety. Crit. Rev. Food Sci. Nutr. 2017, 57, 1681-1687. [CrossRef]

30. Luca, V.S.; Stan, A.M.; Trifan, A.; Miron, A.; Aprotosoaie, A.C. Catechins profile, caffeine content and antioxidant activity of camellia sinensis teas commercialized in romania. Med. Sur. J. Revista Medico-Chirurgicala 2016, 120, 457-463.

31. Satoh, T.; Fujisawa, H.; Nakamura, A.; Takahashi, N.; Watanabe, K. Inhibitory effects of eight green tea catechins on cytochrome p450 1A2, 2C9, 2D6, and 3A4 activities. J. Pharm. Pharm. Sci. 2016, 19, 188-197. [CrossRef] [PubMed]

32. Yang, H.; Xue, X.J.; Li, H.; Apandi, S.N.; Tay-Chan, S.C.; Ong, S.P.; Tian, E.F. The relative antioxidant activity and steric structure of green tea catechins-A kinetic approach. Food Chem. 2018, 257, 399-405. [CrossRef] [PubMed]

33. Bai, W.X.; Wang, C.; Wang, Y.J.; Zheng, W.J.; Wang, W.; Wan, X.C.; Bao, G.H. Novel acylated flavonol tetraglycoside with inhibitory effect on lipid accumulation in 3T3-L1 cells from Lu'an GuaPian tea and quantification of flavonoid glycosides in six major processing types of tea. J. Agric. Food Chem. 2017, 65, 2999-3005. [CrossRef] [PubMed]

34. Chen, G.H.; Lin, Y.L.; Hsu, W.L.; Hsieh, S.K.; Tzen, J. Significant elevation of antiviral activity of strictinin from Pu'er tea after thermal degradation to ellagic acid and gallic acid. J. Food Drug Anal. 2015, 23, 116-123. [CrossRef] [PubMed]

35. Zielinski, A.; Granato, D.; Alberti, A.; Nogueira, A.; Demiate, I.M.; Haminiuk, C. Modelling the extraction of phenolic compounds and in vitro antioxidant activity of mixtures of green, white and black teas (Camellia sinensis L. Kuntze). J. Food Sci. Technol. Mys. 2015, 52, 6966-6977. [CrossRef]

36. De Oliveira, C.C.; Calado, V.; Ares, G.; Granato, D. Statistical approaches to assess the association between phenolic compounds and the in vitro antioxidant activity of Camellia sinensis and Ilex paraguariensis Teas. Crit. Rev. Food Sci. Nutr. 2015, 55, 1456-1473. [CrossRef]

37. Koch, W.; Kukula-Koch, W.; Glowniak, K. Catechin composition and antioxidant activity of black teas in relation to brewing time. J. AOAC Int. 2017, 100, 1694-1699. [CrossRef]

38. Tang, P.; Shen, D.Y.; Xu, Y.Q.; Zhang, X.C.; Shi, J.; Yin, J.F. Effect of fermentation conditions and plucking standards of tea leaves on the chemical components and sensory quality of fermented juice. J. Chem. 2018, 2018, 4312875. [CrossRef] 
39. Sakakibara, H.; Honda, Y.; Nakagawa, S.; Ashida, H.; Kanazawa, K. Simultaneous determination of all polyphenols in vegetables, fruits, and teas. J. Agric. Food Chem. 2003, 51, 571-581. [CrossRef]

40. Bhattacharya, U.; Mukhopadhyay, S.; Giri, A.K. Comparative antimutagenic and anticancer activity of three fractions of black tea polyphenols thearubigins. Nutr. Cancer 2011, 63, 1122-1132. [CrossRef]

41. Weerawatanakorn, M.; Lee, Y.L.; Tsai, C.Y.; Lai, C.S.; Wan, X.C.; Ho, C.T.; Li, S.M.; Pan, M.H. Protective effect of theaflavin-enriched black tea extracts against dimethylnitrosamine-induced liver fibrosis in rats. Food Funct. 2015, 6, 1832-1840. [CrossRef] [PubMed]

42. Xiao, J.B.; Jiang, H.X. A review on the structure-function relationship aspect of polysaccharides from tea materials. Crit. Rev. Food Sci. Nutr. 2015, 55, 930-938. [CrossRef] [PubMed]

43. Fan, M.H.; Sun, X.; Qian, Y.L.; Xu, Y.; Wang, D.F.; Cao, Y.P. Effects of metal ions in tea polysaccharides on their in vitro antioxidant activity and hypoglycemic activity. Int. J. Biol. Macromol. 2018, 113, 418-426. [CrossRef]

44. Park, H.R.; Hwang, D.; Suh, H.J.; Yu, K.W.; Kim, T.Y.; Shin, K.S. Antitumor and antimetastatic activities of rhamnogalacturonan-II-type polysaccharide isolated from mature leaves of green tea via activation of macrophages and natural killer cells. Int. J. Biol. Macromol. 2017, 99, 179-186. [CrossRef] [PubMed]

45. Sun, L.J.; Warren, F.J.; Gidley, M.J. Soluble polysaccharides reduce binding and inhibitory activity of tea polyphenols against porcine pancreatic $\alpha$-amylase. Food Hydrocoll. 2018, 79, 63-70. [CrossRef]

46. Wang, Y.F.; Li, Y.F.; Liu, Y.Y.; Chen, X.Q.; Wei, X.L. Extraction, characterization and antioxidant activities of Se-enriched tea polysaccharides. Int. J. Biol. Macromol. 2015, 77, 76-84. [CrossRef]

47. Wang, H.J.; Shi, S.S.; Bao, B.; Li, X.J.; Wang, S.C. Structure characterization of an arabinogalactan from green tea and its anti-diabetic effect. Carbohyd. Polym. 2015, 124, 98-108. [CrossRef]

48. Xu, Y.; Zhang, M.; Wu, T.; Dai, S.D.; Xu, J.L.; Zhou, Z.K. The anti-obesity effect of green tea polysaccharides, polyphenols and caffeine in rats fed with a high-fat diet. Food Funct. 2015, 6, 297-304. [CrossRef]

49. Yang, X.H.; Huang, M.J.; Qin, C.Q.; Lv, B.Y.; Mao, Q.L.; Liu, Z.H. Structural characterization and evaluation of the antioxidant activities of polysaccharides extracted from Qingzhuan brick tea. Int. J. Biol. Macromol. 2017, 101, 768-775. [CrossRef]

50. Yuan, C.F.; Li, Z.H.; Peng, F.; Xiao, F.X.; Ren, D.M.; Xue, H.; Chen, T.; Mushtaq, G.; Kamal, M.A. Combination of selenium-enriched green tea polysaccharides and Huo-ji polysaccharides synergistically enhances antioxidant and immune activity in mice. J. Sci. Food Agric. 2015, 95, 3211-3217. [CrossRef]

51. Li, X.; Liu, G.J.; Zhang, W.; Zhou, Y.L.; Ling, T.J.; Wan, X.C.; Bao, G.H. Novel flavoalkaloids from white tea with inhibitory activity against the formation of advanced glycation end products. J. Agric. Food Chem. 2018, 66, 4621-4629. [CrossRef] [PubMed]

52. Zhu, Y.C.; Luo, Y.H.; Wang, P.P.; Zhao, M.Y.; Li, L.; Hu, X.S.; Chen, F. Simultaneous determination of free amino acids in Pu-erh tea and their changes during fermentation. Food Chem. 2016, 194, 643-649. [CrossRef] [PubMed]

53. Song, C.W.; Yu, Q.S.; Li, X.H.; Jin, S.N.; Li, S.; Zhang, Y.; Jia, S.L.; Chen, C.; Xiang, Y.; Jiang, H.L. The hypolipidemic effect of total saponins from kuding tea in high-fat diet-induced hyperlipidemic mice and its composition characterized by UPLC-QTOF-MS/MS. J. Food Sci. 2016, 81, H1313-H1319. [CrossRef] [PubMed]

54. Yuan, C.X.; Li, Y.; Li, Q.C.; Jin, R.S.; Ren, L.L. Purification of tea saponins and evaluation of its effect on alcohol dehydrogenase activity. Open Life Sci. 2018, 13, 56-63. [CrossRef]

55. Xu, D.P.; Li, Y.; Meng, X.; Zhou, T.; Zhou, Y.; Zheng, J.; Zhang, J.J.; Li, H.B. Natural antioxidants in foods and medicinal plants: Extraction, assessment and resources. Int. J. Mol. Sci. 2017, 18, 96. [CrossRef]

56. Jiang, X.D.; Feng, K.J.; Yang, X.P. In vitro antifungal activity and mechanism of action of tea polyphenols and tea saponin against Rhizopus stolonifer. J. Mol. Microb. Biotech. 2015, 25, 269-276. [CrossRef] [PubMed]

57. Lin, S.; Chen, Y.X.; Bai, Y.; Cai, H.J.; Wei, H.; Tian, H.J.; Zhao, J.W.; Chen, Y.; Yang, G.; Gu, X.J.; et al. Effect of tea saponin-treated host plants on activities of antioxidant enzymes in larvae of the diamondback moth Plutella Xylostella (Lepidoptera: Plutellidae). Environ. Entomol. 2018, 47, 749-754. [CrossRef]

58. Xu, J.Z.; Yeung, S.; Chang, Q.; Huang, Y.; Chen, Z.Y. Comparison of antioxidant activity and bioavailability of tea epicatechins with their epimers. Br. J. Nutr. 2004, 91, 873-881.

59. Zhu, M.; Chen, Y.; Li, R.C. Oral absorption and bioavailability of tea catechins. Planta Med. 2000, 66, 444-447. [CrossRef]

60. Chen, L.S.; Lee, M.J.; Li, H.; Yang, C.S. Absorption, distribution, and elimination of tea polyphenols in rats. Drug Metab. Dispos. 1997, 25, 1045-1050. 
61. Sun, H.Y.; Chen, Y.H.; Cheng, M.; Zhang, X.; Zheng, X.J.; Zhang, Z.C. The modulatory effect of polyphenols from green tea, oolong tea and black tea on human intestinal microbiota in vitro. J. Food Sci. Technol. Mys. 2018, 55, 399-407. [CrossRef] [PubMed]

62. De Oliveira, D.M.; Sampaio, G.R.; Pinto, C.B.; Catharino, R.R.; Bastos, D. Bioavailability of chlorogenic acids in rats after acute ingestion of mat, tea (Ilex paraguariensis) or 5-caffeoylquinic acid. Eur. J. Nutr. 2017, 56, 2541-2556. [CrossRef] [PubMed]

63. Del Rio, D.; Stalmach, A.; Calani, L.; Crozier, A. Bioavailability of coffee chlorogenic acids and green tea flavan-3-ols. Nutrients 2010, 2, 820-833. [CrossRef] [PubMed]

64. Del Rio, D.; Calani, L.; Cordero, C.; Salvatore, S.; Pellegrini, N.; Brighenti, F. Bioavailability and catabolism of green tea flavan-3-ols in humans. Nutrition 2010, 26, 1110-1116. [CrossRef] [PubMed]

65. Calani, L.; Del Rio, D.; Callegari, M.L.; Morelli, L.; Brighenti, F. Updated bioavailability and 48 h excretion profile of flavan-3-ols from green tea in humans. Int. J. Food Sci. Nutr. 2012, 63, 513-521. [CrossRef]

66. Shahrzad, S.; Aoyagi, K.; Winter, A.; Koyama, A.; Bitsch, I. Pharmacokinetics of gallic acid and its relative bioavailability from tea in healthy humans. J. Nutr. 2001, 131, 1207-1210. [CrossRef]

67. Wiseman, S.; Mulder, T.; Rietveld, A. Tea flavonoids: Bioavailability in vivo and effects on cell signaling pathways in vitro. Antioxid. Redox Sign. 2001, 3, 1009-1021. [CrossRef]

68. Catterall, F.; King, L.J.; Clifford, M.N.; Ioannides, C. Bioavailability of dietary doses of H-3-labelled tea antioxidants (+)-catechin and (-)-epicatechin in rat. Xenobiotica 2003, 33, 743-753. [CrossRef]

69. Del Rio, D.; Calani, L.; Scazzina, F.; Jechiu, L.; Cordero, C.; Brighenti, F. Bioavailability of catechins from ready-to-drink tea. Nutrition 2010, 26, 528-533. [CrossRef]

70. Zhao, D.Y.; Shah, N.P. Concomitant ingestion of lactic acid bacteria and black tea synergistically enhances flavonoid bioavailability and attenuates D-galactose-induced oxidative stress in mice via modulating glutathione antioxidant system. J. Nutr. Biochem. 2016, 38, 116-124. [CrossRef]

71. Choi, E.H.; Lee, D.Y.; Kim, S.; Chung, J.O.; Choi, J.K.; Joo, K.M.; Jeong, H.W.; Kim, J.K.; Kim, W.G.; Shim, S.M. Influence of flavonol-rich excipient food (onion peel and Dendropanax morbifera) on the bioavailability of green tea epicatechins in vitro and in vivo. Food Funct. 2017, 8, 3664-3674. [CrossRef] [PubMed]

72. Kale, A.; Gawande, S.; Kotwal, S.; Netke, S.; Roomi, W.; Ivanov, V.; Niedzwiecki, A.; Rath, M. Studies on the effects of oral administration of nutrient mixture, quercetin and red onions on the bioavailability of epigallocatechin gallate from green tea extract. Phytother. Res. 2010, 241, S48-S55. [CrossRef] [PubMed]

73. Lambert, J.D.; Hong, J.G.; Kim, D.H.; Mishin, V.M.; Yang, C.S. Piperine enhances the bioavailability of the tea polyphenol (-)-epigallocatechin-3-gallate in mice. J. Nutr. 2004, 134, 1948-1952. [CrossRef] [PubMed]

74. Peters, C.M.; Green, R.J.; Janle, E.M.; Ferruzzi, M.G. Formulation with ascorbic acid and sucrose modulates catechin bioavailability from green tea. Food Res. Int. 2010, 43, 95-102. [CrossRef] [PubMed]

75. Wang, P.W.; Heber, D.; Henning, S.M. Quercetin increased bioavailability and decreased methylation of green tea polyphenols in vitro and in vivo. Food Funct. 2012, 3, 635-642. [CrossRef] [PubMed]

76. Naumovski, N.; Blades, B.L.; Roach, P.D. Food inhibits the oral bioavailability of the major green tea antioxidant epigallocatechin gallate in humans. Antioxidants 2015, 4, 373-393. [CrossRef]

77. Chow, H.; Hakim, I.A.; Vining, D.R.; Crowel, J.A.; Ranger-Moore, J.; Chew, W.M.; Celaya, C.A.; Rodney, S.R.; Hara, Y.; Alberts, D.S. Effects of dosing condition on the oral bioavailability of green tea catechins after single-dose administration of Polyphenon E in healthy individuals. Clin. Cancer Res. 2005, 11, 4627-4633. [CrossRef]

78. Egert, S.; Tereszczuk, J.; Wein, S.; Muller, M.J.; Frank, J.; Rimbach, G.; Wolffram, S. Simultaneous ingestion of dietary proteins reduces the bioavailability of galloylated catechins from green tea in humans. Eur. J. Nutr. 2013, 52, 281-288. [CrossRef]

79. James, K.D.; Forester, S.C.; Lambert, J.D. Dietary pretreatment with green tea polyphenol, (-)-epigallocatechin-3-gallate reduces the bioavailability and hepatotoxicity of subsequent oral bolus doses of (-)-epigallocatechin-3-gallate. Food Chem. Toxicol. 2015, 76, 103-108. [CrossRef]

80. Zeng, L.; Luo, L.Y.; Li, H.J.; Liu, R.H. Phytochemical profiles and antioxidant activity of 27 cultivars of tea. Int. J. Food Sci. Nutr. 2017, 68, 525-537. [CrossRef]

81. Liu, S.M.; Huang, H.H. Assessments of antioxidant effect of black tea extract and its rationals by erythrocyte haemolysis assay, plasma oxidation assay and cellular antioxidant activity (CAA) assay. J. Funct. Foods 2015, 18, 1095-1105. [CrossRef] 
82. Peluso, I.; Manafikhi, H.; Raguzzini, A.; Longhitano, Y.; Reggi, R.; Zanza, C.; Palmery, M. The peroxidation of leukocytes index ratio reveals the prooxidant effect of green tea extract. Oxid. Med. Cell Longev. 2016, 2016, 9139731. [CrossRef] [PubMed]

83. Fei, T.Y.; Fei, J.; Huang, F.; Xie, T.P.; Xu, J.F.; Zhou, Y.; Yang, P. The anti-aging and anti-oxidation effects of tea water extract in Caenorhabditis elegans. Exp. Gerontol. 2017, 97, 89-96. [CrossRef] [PubMed]

84. Bartikova, H.; Skalova, L.; Valentova, K.; Matouskova, P.; Szotakova, B.; Martin, J.; Kvita, V.; Bousova, I. Effect of oral administration of green tea extract in various dosage schemes on oxidative stress status of mice in vivo. Acta Pharmaceut. 2015, 65, 65-73. [CrossRef] [PubMed]

85. Jowko, E.; Dlugolecka, B.; Makaruk, B.; Cieslinski, I. The effect of green tea extract supplementation on exercise-induced oxidative stress parameters in male sprinters. Eur. J. Nutr. 2015, 54, 783-791. [CrossRef] [PubMed]

86. Megow, I.; Darvin, M.E.; Meinke, M.C.; Lademann, J. A randomized controlled trial of green tea beverages on the in vivo radical scavenging activity in human skin. Skin Pharmacol. Phys. 2017, 30, 225-233. [CrossRef]

87. Venkatakrishnan, K.; Chiu, H.F.; Cheng, J.C.; Chang, Y.H.; Lu, Y.Y.; Han, Y.C.; Shen, Y.C.; Tsai, K.S.; Wang, C.K. Comparative studies on the hypolipidemic, antioxidant and hepatoprotective activities of catechin-enriched green and oolong tea in a double-blind clinical trial. Food Funct. 2018, 9, 1205-1213. [CrossRef]

88. Hamer, M. The beneficial effects of tea on immune function and inflammation: A review of evidence from in vitro, animal, and human research. Nutr. Res. 2007, 27, 373-379. [CrossRef]

89. Cyboran, S.; Strugala, P.; Wloch, A.; Oszmianski, J.; Kleszczynska, H. Concentrated green tea supplement: Biological activity and molecular mechanisms. Life Sci. 2015, 126, 1-9. [CrossRef]

90. Ben Lagha, A.; Grenier, D. Black tea theaflavins attenuate Porphyromonas gingivalis virulence properties, modulate gingival keratinocyte tight junction integrity and exert anti-inflammatory activity. J. Periodontal Res. 2017, 52, 458-470. [CrossRef]

91. Fechtner, S.; Singh, A.; Chourasia, M.; Ahmed, S. Molecular insights into the differences in anti-inflammatory activities of green tea catechins on IL-1 beta signaling in rheumatoid arthritis synovial fibroblasts. Toxicol. Appl. Pharm. 2017, 329, 112-120. [CrossRef] [PubMed]

92. Liu, L.X.; Wu, X.Q.; Zhang, B.C.; Yang, W.; Li, D.L.; Dong, Y.Q.; Yin, Y.J.; Chen, Q. Protective effects of tea polyphenols on exhaustive exercise-induced fatigue, inflammation and tissue damage. Food Nutr. Res. 2017, 61, 1333390. [CrossRef] [PubMed]

93. Scoparo, C.T.; de Souza, L.M.; Rattmann, Y.D.; Kiatkoski, E.C.; Dartora, N.; Iacomini, M. The protective effect of green and black teas (Camellia sinensis) and their identified compounds against murine sepsis. Food Res. Int. 2016, 83, 102-111. [CrossRef]

94. Shamekhi, Z.; Amani, R.; Habibagahi, Z.; Namjoyan, F.; Ghadiri, A.; Malehi, A.S. A randomized, double-blind, placebo-controlled clinical trial examining the effects of green tea extract on systemic lupus erythematosus disease activity and quality of life. Phytother. Res. 2017, 31, 1063-1071. [CrossRef] [PubMed]

95. Zhang, T.; Li, L.; Liu, Y.H.; Zhong, D.Q.; Tao, Y.; Jiang, X.J.; Xu, Z.Q. Effect of coffee and green tea on executive ability and plasma levels of inflammatory factors in soldiers with 48-hour total sleep deprivation. Int. J. Clin. Exp. Med. 2016, 9, 19354-19362.

96. Suzuki, K.; Takahashi, M.; Li, C.Y.; Lin, S.P.; Tomari, M.; Shing, C.M.; Fang, S.H. The acute effects of green tea and carbohydrate coingestion on systemic inflammation and oxidative stress during sprint cycling. Appl. Physiol. Nutr. Metab. 2015, 40, 997-1003. [CrossRef]

97. Wu, D.Y. Green tea EGCG, T-cell function, and T-cell-mediated autoimmune encephalomyelitis. J. Investig. Med. 2016, 64, 1213-1219. [CrossRef]

98. Joshi, R.; Rana, A.; Kumar, V.; Kumar, D.; Padwad, Y.S.; Yadav, S.K.; Gulati, A. Anthocyanins enriched purple tea exhibits antioxidant, immunostimulatory and anticancer activities. J. Food Sci. Technol. Mys. 2017, 54, 1953-1963. [CrossRef]

99. Sharma, R.; Sharma, A.; Kumari, A.; Kulurkar, P.M.; Raj, R.; Gulati, A.; Padwad, Y.S. Consumption of green tea epigallocatechin-3-gallate enhances systemic immune response, antioxidative capacity and HPA axis functions in aged male swiss albino mice. Biogerontology 2017, 18, 367-382. [CrossRef]

100. Kim, Y.H.; Won, Y.S.; Yang, X.; Kumazoe, M.; Yamashita, S.; Hara, A.; Takagaki, A.; Goto, K.; Nanjo, F.; Tachibana, H. Green tea catechin metabolites exert immunoregulatory effects on $\mathrm{CD}^{+} \mathrm{T}$ cell and natural killer cell activities. J. Agric. Food Chem. 2016, 64, 3591-3597. [CrossRef] 
101. Sil, S.; Bhandari, K.; Gupta, P.; Ghosh, R.; Mitra, A.; Ghosh, B.C.; Ghosh, T. Protective effects of black tea-TV 25 on the cognitive impairments and some peripheral immune responses in intracerebroventricular colchicine injected rats. Orient. Pharm. Exp. Med. 2018, 18, 39-50. [CrossRef]

102. Ahmed, S.T.; Lee, J.W.; Mun, H.S.; Yang, C.J. Effects of supplementation with green tea by-products on growth performance, meat quality, blood metabolites and immune cell proliferation in goats. J. Anim. Physiol. Anim. Nutr. 2015, 99, 1127-1137. [CrossRef] [PubMed]

103. EI-Desouky, W.; Hanafi, A.; Abbas, M.M. Radioprotective effect of green tea and grape seed extracts mixture on gamma irradiation induced immune suppression in male albino rats. Int. J. Radiat. Biol. 2017, 93, 433-439. [CrossRef] [PubMed]

104. Yusni Husni, T.T.; Achmad, T.H. Aktivitas activity of green tea (Camellia sinensis (L) o. Kuntze) polyphenols as immunomodulator through response of suppression immunoglobulin e (IgE) in allergic rhinitis. Majalah Kedokteran Bandung-Mkb-Bandung Med. J. 2015, 47, 160-166. [CrossRef]

105. Krstic, M.; Stojadinovic, M.; Smiljanic, K.; Stanic-Vucinic, D.; Velickovic, T.C. The anticancer activity of green tea, coffee and cocoa extracts on human cervical adenocarcinoma HeLa cells depends on both pro-oxidant and anti-proliferative activities of polyphenols. RSC Adv. 2015, 5, 3260-3268. [CrossRef]

106. Tao, L.; Park, J.Y.; Lambert, J.D. Differential prooxidative effects of the green tea polyphenol, (-)-epigallocatechin-3-gallate, in normal and oral cancer cells are related to differences in sirtuin 3 signaling. Mol. Nutr. Food Res. 2015, 59, 203-211. [CrossRef] [PubMed]

107. Calgarotto, A.K.; Maso, V.; Franchi, G.C.; Nowill, A.E.; Latuf, P.; Vassallo, J.; Saad, S. Antitumor activities of quercetin and green tea in xenografts of human leukemia HL60 cells. Sci. Rep. 2018, 8, 3459. [CrossRef]

108. Torello, C.O.; Shiraishi, R.N.; Della Via, F.I.; de Castro, T.; Longhini, A.L.; Santos, I.; Bombeiro, A.L.; Silva, C.; Queiroz, M.; Rego, E.M.; et al. Reactive oxygen species production triggers green tea-induced anti-leukaemic effects on acute promyelocytic leukaemia model. Cancer Lett. 2018, 414, 116-126. [CrossRef]

109. El-Missiry, M.A.; Abdraboh, M.E.; Othman, A.I.; Abdeen, A.M.; Mohsen, N. Apoptogenic effect of green tea polyphenon-60 against ehrlich ascites carcinoma cells in swiss albino mice. Res. J. Pharm. Biol. Chem. Sci. 2016, 7, 3146-3156.

110. Adami, G.R.; Tangney, C.C.; Tang, J.L.; Zhou, Y.; Ghaffari, S.; Naqib, A.; Sinha, S.; Green, S.J.; Schwartz, J.L. Effects of green tea on miRNA and microbiome of oral epithelium. Sci. Rep. 2018, 8, 5873. [CrossRef]

111. Lassed, S.; Deus, C.M.; Djebbari, R.; Zama, D.; Oliveira, P.J.; Rizvanov, A.A.; Dahdouh, A.; Benayache, F.; Benayache, S. Protective effect of green tea (Camellia sinensis (L.) kuntze) against prostate cancer: From in vitro data to algerian patients. Evid. Based Compl. Altern. 2017, 2017, 1691568. [CrossRef] [PubMed]

112. Micali, S.; Territo, A.; Pirola, G.M.; Ferrari, N.; Sighinolfi, M.C.; Martorana, E.; Navarra, M.; Bianchi, G. Effect of green tea catechins in patients with high-grade prostatic intraepithelial neoplasia: Results of a short-term double-blind placebo controlled phase II clinical trial. Archivio Italiano Di Urologia E Andrologia 2017, 89, 197-202. [CrossRef] [PubMed]

113. Wang, J.Y.; Liu, W.; Chen, Z.Q.; Chen, H.X. Physicochemical characterization of the oolong tea polysaccharides with high molecular weight and their synergistic effects in combination with polyphenols on hepatocellular carcinoma. Biomed. Pharmacother. 2017, 90, 160-170. [CrossRef] [PubMed]

114. Alshatwi, A.A.; Periasamy, V.S.; Athinarayanan, J.; Elango, R. Synergistic anticancer activity of dietary tea polyphenols and bleomycin hydrochloride in human cervical cancer cell: Caspase-dependent and independent apoptotic pathways. Chem. Biol. Interact. 2016, 247, 1-10. [CrossRef] [PubMed]

115. Singh, M.; Bhatnagar, P.; Mishra, S.; Kumar, P.; Shukla, Y.; Gupta, K.C. PLGA-encapsulated tea polyphenols enhance the chemotherapeutic efficacy of cisplatin against human cancer cells and mice bearing Ehrlich ascites carcinoma. Int. J. Nanomed. 2015, 10, 6789-6809. [CrossRef]

116. Mukherjee, S.; Ghosh, S.; Das, D.K.; Chakraborty, P.; Choudhury, S.; Gupta, P.; Adhikary, A.; Dey, S.; Chattopadhyay, S. Gold-conjugated green tea nanoparticles for enhanced anti-tumor activities and hepatoprotection-Synthesis, characterization and in vitro evaluation. J. Nutr. Biochem. 2015, 26, 1283-1297. [CrossRef] [PubMed]

117. Tsai, Y.J.; Chen, B.H. Preparation of catechin extracts and nanoemulsions from green tea leaf waste and their inhibition effect on prostate cancer cell PC-3. Int. J. Nanomed. 2016, 11, 1907-1926.

118. Nakachi, K.; Matsuyama, S.; Miyake, S.; Suganuma, M.; Imai, K. Preventive effects of drinking green tea on cancer and cardiovascular disease: Epidemiological evidence for multiple targeting prevention. Biofactors 2000, 13, 49-54. [CrossRef] 
119. Serban, C.; Sahebkar, A.; Antal, D.; Ursoniu, S.; Banach, M. Effects of supplementation with green tea catechins on plasma C-reactive protein concentrations: A systematic review and meta-analysis of randomized controlled trials. Nutrition 2015, 31, 1061-1071. [CrossRef]

120. Ueshima, H. Explanation for the Japanese paradox: Prevention of increase in coronary heart disease and reduction in stroke. J. Atheroscler. Thromb. 2007, 14, 278-286. [CrossRef]

121. Zeng, L.; Yan, J.N.; Luo, L.Y.; Zhang, D.Y. Effects of Pu-erh tea aqueous extract (PTAE) on blood lipid metabolism enzymes. Food Funct. 2015, 6, 2008-2016. [CrossRef] [PubMed]

122. Yang, T.; Koo, M. Inhibitory effect of Chinese green tea on endothelial cell-induced LDL oxidation. Atherosclerosis 2000, 148, 67-73. [CrossRef]

123. Shibu, M.A.; Kuo, C.H.; Chen, B.C.; Ju, D.T.; Chen, R.J.; Lai, C.H.; Huang, P.J.; Viswanadha, V.P.; Kuo, W.W.; Huang, C.Y. Oolong tea prevents cardiomyocyte loss against hypoxia by attenuating p-JNK mediated hypertrophy and enhancing P-IGF1R, p-akt, and p-Bad(ser136) activity and by fortifying NRF2 antioxidation system. Environ. Toxicol. 2018, 33, 220-233. [CrossRef] [PubMed]

124. Garcia, M.L.; Pontes, R.B.; Nishi, E.E.; Ibuki, F.K.; Oliveira, V.; Sawaya, A.; Carvalho, P.O.; Nogueira, F.N.; Franco, M.D.; Campos, R.R.; et al. The antioxidant effects of green tea reduces blood pressure and sympathoexcitation in an experimental model of hypertension. J. Hypertens. 2017, 35, 348-354. [CrossRef]

125. Szulinska, M.; Stepien, M.; Kregielska-Narozna, M.; Suliburska, J.; Skrypnik, D.; Bak-Sosnowska, M.; Kujawska-Luczak, M.; Grzymislawska, M.; Bogdanski, P. Effects of green tea supplementation on inflammation markers, antioxidant status and blood pressure in $\mathrm{NaCl}$-induced hypertensive rat model. Food Nutr. Res. 2017, 61, 1295525. [CrossRef]

126. Li, S.B.; Li, Y.F.; Mao, Z.F.; Hu, H.H.; Ouyang, S.H.; Wu, Y.P.; Tsoi, B.; Gong, P.; Kurihara, H.; He, R.R. Differing chemical compositions of three teas may explain their different effects on acute blood pressure in spontaneously hypertensive rats. J. Sci. Food Agric. 2015, 95, 1236-1242. [CrossRef]

127. Xu, P.; Ying, L.; Wu, J.; Kong, D.D.; Wang, Y.F. Safety evaluation and antihyperlipidemia effect of aqueous extracts from fermented puerh tea. Food Funct. 2016, 7, 2667-2674. [CrossRef]

128. Seo, D.B.; Jeong, H.W.; Kim, Y.J.; Kim, S.; Kim, J.; Lee, J.H.; Joo, K.; Choi, J.K.; Shin, S.S.; Lee, S.J. Fermented green tea extract exhibits hypolipidaemic effects through the inhibition of pancreatic lipase and promotion of energy expenditure. Brit. J. Nutr. 2017, 117, 177-186. [CrossRef]

129. Nakamura, M.; Miura, S.; Takagaki, A.; Nanjo, F. Hypolipidemic effects of crude green tea polysaccharide on rats, and structural features of tea polysaccharides isolated from the crude polysaccharide. Int. J. Food Sci. Nutr. 2017, 68, 321-330. [CrossRef]

130. Mao, Y.; Wei, B.Y.; Teng, J.W.; Xia, N.; Zhao, M.M.; Huang, L.; Ye, Y. Polysaccharides from Chinese Liupao dark tea and their protective effect against hyperlipidemia. Int. J. Food Sci. Technol. 2018, 53, 599-607. [CrossRef]

131. Li, Y.F.; Chang, Y.Q.; Deng, J.; Li, W.X.; Jian, J.; Gao, J.S.; Wan, X.; Gao, H.; Kurihara, H.; Sun, P.H.; et al. Prediction and evaluation of the lipase inhibitory activities of tea polyphenols with 3D-QSAR models. Sci. Rep. 2016, 6, 34387. [CrossRef]

132. Leung, F.P.; Yung, L.M.; Ngai, C.Y.; Cheang, W.S.; Tian, X.Y.; Lau, C.W.; Zhang, Y.; Liu, J.; Chen, Z.Y.; Bian, Z.X.; et al. Chronic black tea extract consumption improves endothelial function in ovariectomized rats. Eur. J. Nutr. 2016, 55, 1963-1972. [CrossRef]

133. Jang, H.J.; Ridgeway, S.D.; Kim, J.A. Effects of the green tea polyphenol epigallocatechin-3-gallate on high-fat diet-induced insulin resistance and endothelial dysfunction. Am. J. Physiol.-Endoc. Metab. 2013, 305, E1444-E1451. [CrossRef]

134. Potenza, M.A.; Marasciulo, F.L.; Tarquinio, M.; Tiravanti, E.; Colantuono, G.; Federici, A.; Kim, J.A.; Quon, M.J.; Montagnani, M. EGCG, a green tea polyphenol, improves endothelial function and insulin sensitivity, reduces blood pressure, and protects against myocardial I/R injury in SHR. Am. J. Physiol. Endoc. Metab. 2007, 292, E1378-E1387. [CrossRef]

135. Nogueira, L.D.; Neto, J.; Klein, M.; Sanjuliani, A.F. Short-term effects of green tea on blood pressure, endothelial function, and metabolic profile in obese prehypertensive women: A crossover randomized clinical trial. J. Am. Coll. Nutr. 2017, 36, 108-115. [CrossRef]

136. Woodward, K.A.; Hopkins, N.D.; Draijer, R.; de Graaf, Y.; Low, D.A.; Thijssen, D. Acute black tea consumption improves cutaneous vascular function in healthy middle-aged humans. Clin. Nutr. 2018, 37, 242-249. [CrossRef] 
137. Grassi, D.; Draijer, R.; Schalkwijk, C.; Desideri, G.; D’Angeli, A.; Francavilla, S.; Mulder, T.; Ferri, C. Black tea increases circulating endothelial progenitor cells and improves flow mediated dilatation counteracting deleterious effects from a fat load in hypertensive patients: A randomized controlled study. Nutrients 2016, 8 , 727. [CrossRef]

138. Oyama, J.; Maeda, T.; Kouzuma, K.; Ochiai, R.; Tokimitsu, I.; Higuchi, Y.; Sugano, M.; Makino, N. Green tea catechins improve human forearm endothelial dysfunction and have antiatherosclerotic effects in smokers. Circ. J. 2010, 74, 578-588. [CrossRef]

139. Lorenz, M.; Rauhut, F.; Hofer, C.; Gwosc, S.; Muller, E.; Praeger, D.; Zimmermann, B.F.; Wernecke, K.D.; Baumann, G.; Stangl, K.; et al. Tea-induced improvement of endothelial function in humans: No role for epigallocatechin gallate (EGCG). Sci. Rep. 2017, 7, 2279. [CrossRef]

140. Jochmann, N.; Lorenz, M.; von Krosigk, A.; Martus, P.; Bohm, V.; Baumann, G.; Stangl, K.; Stangl, V. The efficacy of black tea in ameliorating endothelial function is equivalent to that of green tea. Br. J. Nutr. 2008, 99, 863-868. [CrossRef]

141. Samavat, H.; Newman, A.R.; Wang, R.W.; Yuan, J.M.; Wu, A.H.; Kurzer, M.S. Effects of green tea catechin extract on serum lipids in postmenopausal women: A randomized, placebo-controlled clinical trial. Am. J. Clin. Nutr. 2016, 104, 1671-1682. [CrossRef] [PubMed]

142. Orem, A.; Alasalvar, C.; Kural, B.V.; Yaman, S.; Orem, C.; Karadag, A.; Pelvan, E.; Zawistowski, J. Cardio-protective effects of phytosterol-enriched functional black tea in mild hypercholesterolemia subjects. J. Funct. Foods 2017, 31, 311-319. [CrossRef]

143. Troup, R.; Hayes, J.H.; Raatz, S.K.; Thyagarajan, B.; Khaliq, W.; Jacobs, D.R.; Key, N.S.; Morawski, B.M.; Kaiser, D.; Bank, A.J.; et al. Effect of black tea intake on blood cholesterol concentrations in individuals with mild hypercholesterolemia: A Diet-controlled randomized trial. J. Acad. Nutr. Diet 2015, 115, $264-\mathrm{U} 1122$. [CrossRef] [PubMed]

144. Oh, J.; Jo, S.H.; Kim, J.S.; Ha, K.S.; Lee, J.Y.; Choi, H.Y.; Yu, S.Y.; Kwon, Y.I.; Kim, Y.C. 1 Selected tea and tea pomace extracts inhibit intestinal $\alpha$-Glucosidase activity in vitro and postprandial hyperglycemia in vivo. Int. J. Mol. Sci. 2015, 16, 8811-8825. [CrossRef] [PubMed]

145. Satoh, T.; Igarashi, M.; Yamada, S.; Takahashi, N.; Watanabe, K. Inhibitory effect of black tea and its combination with acarbose on small intestinal $\alpha$-glucosidase activity. J. Ethnopharmacol. 2015, 161, 147-155. [CrossRef] [PubMed]

146. Deng, Y.T.; Lin-Shiau, S.Y.; Shyur, L.F.; Lin, J.K. Pu-erh tea polysaccharides decrease blood sugar by inhibition of $\alpha$-glucosidase activity in vitro and in mice. Food Funct. 2015, 6, 1539-1546. [CrossRef]

147. Li, S.Q.; Chen, H.X.; Wang, J.; Wang, X.M.; Hu, B.; Lv, F.N. Involvement of the PI3K/Akt signal pathway in the hypoglycemic effects of tea polysaccharides on diabetic mice. Int. J. Biol. Macromol. 2015, 81, 967-974. [CrossRef]

148. Han, M.M.; Zhao, G.S.; Wang, Y.J.; Wang, D.X.; Sun, F.; Ning, J.M.; Wan, X.C.; Zhang, J.S. Safety and anti-hyperglycemic efficacy of various tea types in mice. Sci. Rep. 2016, 6, 31703. [CrossRef]

149. Lee, J.E.; Kang, S.J.; Choi, S.H.; Song, C.H.; Lee, Y.J.; Ku, S.K. Fermentation of green tea with $2 \%$ aquilariae lignum increases the anti-diabetic activity of green tea aqueous extracts in the high fat-fed mouse. Nutrients 2015, 7, 9046-9078. [CrossRef]

150. Mahmoud, F.; Haines, D.; Al-Ozairi, E.; Dashti, A. Effect of black tea consumption on intracellular cytokines, regulatory T cells and metabolic biomarkers in type 2 diabetes patients. Phytother. Res. 2016, 30, 454-462. [CrossRef]

151. Jiao, H.; Hu, G.H.; Gu, D.Y.; Ni, X.L. Having a promising efficacy on type II diabetes, it's definitely a green tea time. Curr. Med. Chem. 2015, 22, 70-79. [CrossRef] [PubMed]

152. Suraphad, P.; Suklaew, P.O.; Ngamukote, S.; Adisakwattana, S.; Makynen, K. The effect of isomaltulose together with green tea on glycemic response and antioxidant capacity: A single-blind, crossover study in healthy subjects. Nutrients 2017, 9, 464. [CrossRef] [PubMed]

153. De Amorim, L.; Vaz, S.R.; Cesario, G.; Coelho, A.; Botelho, P.B. Effect of green tea extract on bone mass and body composition in individuals with diabetes. J. Funct Foods 2018, 40, 589-594. [CrossRef]

154. Roberto, B.S.; Macedo, G.A.; Macedo, J.A.; Martins, I.M.; Nakajima, V.M.; Allwood, J.W.; Stewart, D.; McDougall, G.J. Immobilized tannase treatment alters polyphenolic composition in teas and their potential anti-obesity and hypoglycemic activities in vitro. Food Funct. 2016, 7, 3920-3932. [CrossRef] 
155. Lao, W.G.; Tan, Y.; Jin, X.L.; Xiao, L.D.; Kim, J.; Qu, X.Q. Comparison of cytotoxicity and the anti-adipogenic effect of green tea polyphenols with epigallocatechin-3-gallate in 3T3-L1 preadipocytes. Am. J. Chin. Med. 2015, 43, 1177-1190. [CrossRef]

156. Choi, J.Y.; Kim, Y.J.; Ryu, R.; Cho, S.J.; Kwon, E.Y.; Choi, M.S. Effect of green tea extract on systemic metabolic homeostasis in diet-induced obese mice determined via RNA-Seq transcriptome profiles. Nutrients 2016, 8, 640. [CrossRef]

157. Nam, M.; Choi, M.S.; Choi, J.Y.; Kim, N.; Kim, M.S.; Jung, S.; Kim, J.; Ryu, D.H.; Hwang, G.S. Effect of green tea on hepatic lipid metabolism in mice fed a high-fat diet. J. Nutr. Biochem. 2018, 51, 1-7. [CrossRef]

158. Liu, Z.B.; Chen, Z.C.; Guo, H.W.; He, D.P.; Zhao, H.R.; Wang, Z.Y.; Zhang, W.; Liao, L.; Zhang, C.; Ni, L. The modulatory effect of infusions of green tea, oolong tea, and black tea on gut microbiota in high-fat-induced obese mice. Food Funct. 2016, 7, 4869-4879. [CrossRef]

159. Cheng, M.; Zhang, X.; Zhu, J.Y.; Cheng, L.; Cao, J.X.; Wu, Z.F.; Weng, P.F.; Zheng, X.J. A metagenomics approach to the intestinal microbiome structure and function in high fat diet-induced obesity mice fed with oolong tea polyphenols. Food Funct. 2018, 9, 1079-1087. [CrossRef]

160. Wang, L.; Zeng, B.H.; Zhang, X.J.; Liao, Z.L.; Gu, L.H.; Liu, Z.W.; Zhong, Q.P.; Wei, H.; Fang, X. The effect of green tea polyphenols on gut microbial diversity and fat deposition in C57BL/6J HFA mice. Food Funct. 2016, 7, 4956-4966. [CrossRef]

161. Chen, I.J.; Liu, C.Y.; Chiu, J.P.; Hsu, C.H. Therapeutic effect of high-dose green tea extract on weight reduction: A randomized, double-blind, placebo-controlled clinical trial. Clin. Nutr. 2016, 35, 592-599. [CrossRef] [PubMed]

162. Taghizadeh, M.; Farzin, N.; Taheri, S.; Mahlouji, M.; Akbari, H.; Karamali, F.; Asemi, Z. The effect of dietary supplements containing green tea, capsaicin and ginger extracts on weight loss and metabolic profiles in overweight women: A randomized double-blind placebo-controlled clinical trial. Ann. Nutr. Metab. 2017, 70, 277-285. [CrossRef] [PubMed]

163. Roberts, J.D.; Roberts, M.G.; Tarpey, M.D.; Weekes, J.C.; Thomas, C.H. The effect of a decaffeinated green tea extract formula on fat oxidation, body composition and exercise performance. J. Int. Soc. Sport Nutr. 2015, 12, 1. [CrossRef] [PubMed]

164. Afzalpour, M.E.; Ghasemi, E.; Zarban, A. Effects of 10 weeks of high intensity interval training and green tea supplementation on serum levels of Sirtuin-1 and peroxisome proliferator-activated receptor gamma co-activator 1- $\alpha$ in overweight women. Sci. Sport. 2017, 32, 82-90. [CrossRef]

165. Gahreman, D.; Heydari, M.; Boutcher, Y.; Freund, J.; Boutcher, S. The effect of green tea ingestion and interval sprinting exercise on the body composition of overweight males: A randomized trial. Nutrients 2016, 8, 510. [CrossRef]

166. Meng, X.; Li, Y.; Li, S.; Gan, R.Y.; Li, H.B. Natural products for prevention and treatment of chemical-induced liver injuries. Compr. Rev. Food Sci. Food Saf. 2018, 17, 472-495. [CrossRef]

167. Xiao, M.L.; Chen, G.D.; Zeng, F.F.; Qiu, R.; Shi, W.Q.; Lin, J.S.; Cao, Y.; Li, H.B.; Ling, W.H.; Chen, Y.M. Higher serum carotenoids associated with improvement of non-alcoholic fatty liver disease in adults: A prospective study. Eur. J. Nutr. 2018, 58, 721-730. [CrossRef]

168. Zhang, J.J.; Meng, X.; Li, Y.; Zhou, Y.; Xu, D.P.; Li, S.; Li, H.B. Effects of melatonin on liver injuries and diseases. Int. J. Mol. Sci. 2017, 18, 673. [CrossRef]

169. Zhang, Y.J.; Zhou, T.; Wang, F.; Zhou, Y.; Li, Y.; Zhang, J.J.; Zheng, J.; Xu, D.P.; Li, H.B. The effects of Syzygium samarangense, Passiflora edulis and Solanum muricatum on alcohol-induced liver injury. Int. J. Mol. Sci. 2016, 17, 1616. [CrossRef]

170. Zhou, T.; Zhang, Y.J.; Xu, D.P.; Wang, F.; Zhou, Y.; Zheng, J.; Li, Y.; Zhang, J.J.; Li, H.B. Protective effects of lemon juice on alcohol-induced liver injury in mice. Biomed. Res. Int. 2017, 2017, 7463571. [CrossRef]

171. Braud, L.; Battault, S.; Meyer, G.; Nascimento, A.; Gaillard, S.; de Sousa, G.; Rahmani, R.; Riva, C.; Armand, M.; Maixent, J.M.; et al. Antioxidant properties of tea blunt ROS-dependent lipogenesis: Beneficial effect on hepatic steatosis in a high fat-high sucrose diet NAFLD obese rat model. J. Nutr. Biochem. 2017, 40, 95-104. [CrossRef] [PubMed]

172. Rangi, S.; Dhatwalia, S.K.; Bhardwaj, P.; Kumar, M.; Dhawan, D.K. Evidence of similar protective effects afforded by white tea and its active component 'EGCG' on oxidative-stress mediated hepatic dysfunction during benzo(a)pyrene induced toxicity. Food Chem. Toxicol. 2018, 116, 281-291. [CrossRef] [PubMed] 
173. Reddyvari, H.; Govatati, S.; Matha, S.K.; Korla, S.V.; Malempati, S.; Pasupuleti, S.R.; Bhanoori, M.; Nallanchakravarthula, V. Therapeutic effect of green tea extract on alcohol induced hepatic mitochondrial DNA damage in albino wistar rats. J. Adv. Res. 2017, 8, 289-295. [CrossRef] [PubMed]

174. Li, W.F.; Huang, D.; Gao, A.N.; Yang, X.B. Stachyose increases absorption and hepatoprotective effect of tea polyphenols in high fructose-fed mice. Mol. Nutr. Food Res. 2016, 60, 502-510. [CrossRef] [PubMed]

175. Hu, W.Y.; Ma, X.H.; Zhou, W.Y.; Li, X.X.; Sun, T.T.; Sun, H. Preventive effect of Silibinin in combination with Pu-erh tea extract on non-alcoholic fatty liver disease in ob/ob mice. Food Funct. 2017, 8, 1105-1115. [CrossRef] [PubMed]

176. Singh, D.P.; Singh, J.; Boparai, R.K.; Zhu, J.H.; Mantri, S.; Khare, P.; Khardori, R.; Kondepudi, K.K.; Chopra, K.; Bishnoi, M. Isomalto-oligosaccharides, a prebiotic, functionally augment green tea effects against high fat diet-induced metabolic alterations via preventing gut dysbacteriosis in mice. Pharmacol. Res. 2017, 123, 103-113. [CrossRef] [PubMed]

177. Pezeshki, A.; Safi, S.; Feizi, A.; Askari, G.; Karami, F. The effect of green tea extract supplementation on liver enzymes in patients with nonalcoholic fatty liver disease. Int. J. Prev. Med. 2016, 7, 131.

178. Delwing-Dal Magro, D.; Roecker, R.; Junges, G.M.; Rodrigues, A.F.; Delwing-de Lima, D.; Da Cruz, J.; Wyse, A.; Pitz, H.S.; Zeni, A. Protective effect of green tea extract against proline-induced oxidative damage in the rat kidney. Biomed. Pharmacother. 2016, 83, 1422-1427. [CrossRef]

179. Lv, J.; Feng, M.; Zhang, L.L.; Wan, X.; Zeng, Y.C.; Liang, P.F.; Xu, A.P. Protective effect of epigallocatechin gallate, a major constituent of green tea, against renal ischemia-reperfusion injury in rats. Int. Urol. Nephrol. 2015, 47, 1429-1435. [CrossRef]

180. Veljkovic, M.; Pavlovic, D.R.; Stojiljkovic, N.; Ilic, S.; Petrovic, A.; Jovanovic, I.; Radenkovic, M. Morphological and morphometric study of protective effect of green tea in gentamicin-induced nephrotoxicity in rats. Life Sci. 2016, 147, 85-91. [CrossRef]

181. Wang, H.D.; Li, D.Y.; Hu, Z.Z.; Zhao, S.M.; Zheng, Z.J.; Li, W. Protective effects of green tea polyphenol against renal injury through ROS-mediated JNK-MAPK pathway in lead exposed rats. Mol. Cells 2016, 39, 508-513. [CrossRef] [PubMed]

182. Xie, X.; Yi, W.J.; Zhang, P.W.; Wu, N.N.; Yan, Q.Q.; Yang, H.; Tian, C.; Xiang, S.Y.; Du, M.Y.; Assefa, E.G.; et al. Green tea polyphenols, mimicking the effects of dietary restriction, ameliorate high-fat diet-induced kidney injury via regulating autophagy flux. Nutrients 2017, 9, 497. [CrossRef] [PubMed]

183. Ye, T.; Zhen, J.H.; Du, Y.; Zhou, J.K.; Peng, A.; Vaziri, N.D.; Mohan, C.; Xu, Y.; Zhou, X.J. Green tea polyphenol (-)-epigallocatechin-3-gallate restores nrf2 activity and ameliorates crescentic glomerulonephritis. PLoS ONE 2015, 10, e0119543.

184. Arab, H.; Mahjoub, S.; Hajian-Tilaki, K.; Moghadasi, M. The effect of green tea consumption on oxidative stress markers and cognitive function in patients with Alzheimer's disease: A prospective intervention study. Casp. J. Int. Med. 2016, 7, 188-194.

185. Cai, S.X.; Yang, H.; Wen, B.B.; Zhu, K.; Zheng, X.; Huang, J.A.; Wang, Y.Z.; Liu, Z.H.; Tu, P.F. Inhibition by microbial metabolites of Chinese dark tea of age- related neurodegenerative disorders in senescenceaccelerated mouse prone 8 (SAMP8) mice. Food Funct. 2018, 9, 5455-5462. [CrossRef] [PubMed]

186. Di Lorenzo, A.; Nabavi, S.F.; Sureda, A.; Moghaddam, A.H.; Khanjani, S.; Arcidiaco, P.; Nabavi, S.M.; Daglia, M. Antidepressive-like effects and antioxidant activity of green tea and GABA green tea in a mouse model of post-stroke depression. Mol. Nutr. Food Res. 2016, 60, 566-579. [CrossRef]

187. Schimidt, H.L.; Garcia, A.; Martins, A.; Mello-Carpes, P.B.; Carpes, F.P. Green tea supplementation produces better neuroprotective effects than red and black tea in Alzheimer-like rat model. Food Res. Int. 2017, 100, 442-448. [CrossRef]

188. Teng, J.; Zhou, W.; Zeng, Z.; Zhao, W.F.; Huang, Y.H.; Zhang, X. Quality components and antidepressant-like effects of GABA green tea. Food Funct. 2017, 8, 3311-3318. [CrossRef]

189. Mathiyazahan, D.B.; Thenmozhi, A.J.; Manivasagam, T. Protective effect of black tea extract against aluminium chloride-induced Alzheimer's disease in rats: A behavioural, biochemical and molecular approach. J. Funct. Foods 2015, 16, 423-435. [CrossRef]

190. Qi, G.Y.; Mi, Y.S.; Liu, Z.G.; Fan, R.; Qiao, Q.L.; Sun, Y.L.; Ren, B.; Liu, X.B. Dietary tea polyphenols ameliorate metabolic syndrome and memory impairment via circadian clock related mechanisms. J. Funct. Foods 2017, 34, 168-180. [CrossRef] 
191. Foster, M.T.; Gentile, C.L.; Cox-York, K.; Wei, Y.R.; Wang, D.; Estrada, A.L.; Reese, L.; Miller, T.; Pagliassotti, M.J.; Weir, T.L. Fuzhuan tea consumption imparts hepatoprotective effects and alters intestinal microbiota in high saturated fat diet-fed rats. Mol. Nutr. Food Res. 2016, 60, 1213-1220. [CrossRef] [PubMed]

192. Scoparo, C.T.; Souza, L.M.; Dartora, N.; Sassaki, G.L.; Santana, A.P.; Werner, M.; Borato, D.G.; Baggio, C.H.; Iacomini, M. Chemical characterization of heteropolysaccharides from green and black teas (Camellia sinensis) and their anti-ulcer effect. Int. J. Biol. Macromol. 2016, 86, 772-781. [CrossRef] [PubMed]

193. Wang, Y.L.; Xu, A.Q.; Liu, P.; Li, Z.J. Effects of Fuzhuan brick-tea water extract on mice infected with E. coli O157:H7. Nutrients 2015, 7, 5309-5326. [CrossRef] [PubMed]

194. Yang, J.N.; Zhou, W.Y.; Gu, Y.R.; Dai, J.W.; Li, X.X.; Tai, P.; Li, Y.C.; Ma, X.H.; Zhang, Y.Y. Protective effect of Pu-erh tea extracts against ethanol-induced gastric mucosal damage in rats. Biomed. Rep. 2018, 8, 335-342. [CrossRef] [PubMed]

195. Yi, R.; Wang, R.; Sun, P.; Zhao, X. Antioxidant-mediated preventative effect of dragon-pearl tea crude polyphenol extract on reserpine-induced gastric ulcers. Exp. Therap. Med. 2015, 10, 338-344. [CrossRef] [PubMed]

196. Lu, X.J.; Liu, J.X.; Zhang, N.S.; Fu, Y.H.; Zhang, Z.C.; Li, Y.X.; Wang, W.Q.; Li, Y.Y.; Shen, P.; Cao, Y.G. Ripened $\mathrm{Pu}$-erh tea extract protects mice from obesity by modulating gut microbiota composition. J. Agric. Food Chem. 2019, 67, 6978-6994. [CrossRef] [PubMed]

197. Liu, J.H.; Hao, W.J.; He, Z.Y.; Kwek, E.; Zhao, Y.M.; Zhu, H.Y.; Liang, N.; Ma, K.Y.; Lei, L.; He, W.S.; et al. Beneficial effects of tea water extracts on the body weight and gut microbiota in C57BL/6J mice fed with a high-fat diet. Food Funct. 2019, 10, 2847-2860. [CrossRef]

198. Zhang, X.; Zhang, M.; Ho, C.T.; Guo, X.J.; Wu, Z.F.; Weng, P.F.; Yan, M.D.; Cao, J.X. Metagenomics analysis of gut microbiota modulatory effect of green tea polyphenols by high fat diet-induced obesity mice model. J. Funct. Foods 2018, 46, 268-277. [CrossRef]

199. Chen, G.J.; Xie, M.H.; Dai, Z.Q.; Wan, P.; Ye, H.; Zeng, X.X.; Sun, Y. Kudingcha and fuzhuan brick tea prevent obesity and modulate gut microbiota in high-fat diet fed mice. Mol. Nutr. Food Res. 2018, 62, 1700485. [CrossRef]

200. Zhou, J.; Tang, L.L.; Shen, C.L.; Wang, J.S. Green tea polyphenols modify gut-microbiota dependent metabolisms of energy, bile constituents and micronutrients in female Sprague-Dawley rats. J. Nutr. Biochem. 2018, 61, 68-81. [CrossRef]

201. Chen, G.J.; Xie, M.H.; Wan, P.; Chen, D.; Dai, Z.Q.; Ye, H.; Hu, B.; Zeng, X.X.; Liu, Z.H. Fuzhuan brick tea polysaccharides attenuate metabolic syndrome in high-fat diet induced mice in association with modulation in the gut microbiota. J. Agric. Food Chem. 2018, 66, 2783-2795. [CrossRef] [PubMed]

202. Ma, H.; Zhang, B.W.; Hu, Y.Z.; Wang, J.; Liu, J.M.; Qui, R.B.; Lv, S.W.; Wang, S. Correlation analysis of intestinal redox state with the gut microbiota reveals the positive intervention of tea polyphenols on hyperlipidemia in high fat diet fed mice. J. Agric. Food Chem. 2019, 67, 7325-7335. [CrossRef] [PubMed]

203. Barroso, H.; Ramalhete, R.; Domingues, A.; Maci, S. Inhibitory activity of a green and black tea blend on Streptococcus mutans. J. Oral Microbiol. 2018, 10, 1481322. [CrossRef] [PubMed]

204. Chen, M.; Zhai, L.; Arendrup, M.C. In vitro activity of 23 tea extractions and epigallocatechin gallate against Candida species. Med. Mycol. 2015, 53, 194-198. [CrossRef]

205. Gopal, J.; Muthu, M.; Paul, D.; Kim, D.H.; Chun, S. Bactericidal activity of green tea extracts: The importance of catechin containing nano particles. Sci. Rep. 2016, 6, 19710. [CrossRef]

206. Li, Z.P.; Summanen, P.H.; Downes, J.; Corbett, K.; Komoriya, T.; Henning, S.M.; Kim, J.; Finegold, S.M. Antimicrobial activity of pomegranate and green tea extract on propionibacterium acnes, propionibacterium granulosum, staphylococcus aureus and staphylococcus epidermidis. J. Drugs Dermatol. 2015, 14, 574-578.

207. Pandey, R.; Ter Beek, A.; Vischer, N.; Smelt, J.; Kemperman, R.; Manders, E.; Brul, S. Quantitative analysis of the effect of specific tea compounds on germination and outgrowth of Bacillus subtilis spores at single cell resolution. Food Microbiol. 2015, 45, 63-70. [CrossRef]

208. Randazzo, W.; Falco, I.; Aznar, R.; Sanchez, G. Effect of green tea extract on enteric viruses and its application as natural sanitizer. Food Microbiol. 2017, 66, 150-156. [CrossRef]

209. Gurusubramanian, G.; Rahman, A.; Sarmah, M.; Ray, S.; Bora, S. Pesticide usage pattern in tea ecosystem, their retrospects and alternative measures. J. Environ. Biol. 2008, 29, 813-826. 
210. Isomura, T.; Suzuki, S.; Origasa, H.; Hosono, A.; Suzuki, M.; Sawada, T.; Terao, S.; Muto, Y.; Koga, T. Liver-related safety assessment of green tea extracts in humans: A systematic review of randomized controlled trials. Eur. J. Clin. Nutr. 2016, 70, 1221-1229. [CrossRef]

211. Zhao, Z.J.; Hu, X.C.; Liu, Q.J. Recent advances on the fungi of Pu-erh ripe tea. Int. Food Res. J. 2015, 22, 1240-1246.

212. Nkansah, M.A.; Opoku, F.; Ackumey, A.A. Risk assessment of mineral and heavy metal content of selected tea products from the Ghanaian market. Environ. Monit. Assess. 2016, 188, 332. [CrossRef] [PubMed]

213. Zhang, J.; Yang, R.D.; Chen, R.; Peng, Y.S.; Wen, X.F.; Gao, L. Accumulation of heavy metals in tea leaves and potential health risk assessment: A case study from Puan county, Guizhou province, China. Int. J. Environ. Res. Public Health 2018, 15, 133. [CrossRef] [PubMed]

214. Li, L.H.; Fu, Q.L.; Achal, V.; Liu, Y.L. A comparison of the potential health risk of aluminum and heavy metals in tea leaves and tea infusion of commercially available green tea in Jiangxi, China. Environ. Monit. Assess. 2015, 187, 228. [CrossRef]

215. Chen, H.P.; Wang, Q.H.; Jiang, Y.; Wang, C.P.; Yin, P.; Liu, X.; Lu, C.Y. Monitoring and risk assessment of 74 pesticide residues in Pu-erh tea produced in Yunnan, China. Food Addit. Contam. B 2015, 8, 56-62. [CrossRef]

216. Huo, F.F.; Tang, H.; Wu, X.; Chen, D.Z.; Zhao, T.; Liu, P.; Li, L. Utilizing a novel sorbent in the solid phase extraction for simultaneous determination of 15 pesticide residues in green tea by GC/MS. J. Chromatogr. $B$ 2016, 1023, 44-54. [CrossRef]

217. Feng, J.; Tang, H.; Chen, D.Z.; Li, L. Monitoring and risk assessment of pesticide residues in tea samples from china. Hum. Ecol. Risk Assess. 2015, 21, 169-183. [CrossRef]

218. Li, J.X.; Sun, M.Y.; Chang, Q.Y.; Hu, X.Y.; Kang, J.; Fan, C.L. Determination of pesticide residues in teas via QuEChERS combined with dispersive liquid-liquid microextraction followed by gas chromatography-tandem mass spectrometry. Chromatographia 2017, 80, 1447-1458. [CrossRef]

219. Cao, Y.L.; Tang, H.; Chen, D.Z.; Li, L. A novel method based on MSPD for simultaneous determination of 16 pesticide residues in tea by LC-MS/MS. J. Chromatogr. B 2015, 998, 72-79. [CrossRef]

220. Martinez-Dominguez, G.; Romero-Gonzalez, R.; Frenich, A.G. Multi-class methodology to determine pesticides and mycotoxins in green tea and royal jelly supplements by liquid chromatography coupled to Orbitrap high resolution mass spectrometry. Food Chem. 2016, 197, 907-915. [CrossRef]

221. Haas, D.; Pfeifer, B.; Reiterich, C.; Partenheimer, R.; Reck, B.; Buzina, W. Identification and quantification of fungi and mycotoxins from Pu-erh tea. Int. J. Food Microbiol. 2013, 166, 316-322. [CrossRef] [PubMed]

222. Liu, Z.; Liu, D.Y.; Cheng, J.G.; Mei, S.; Fu, Y.; Lai, W.Q.; Wang, Y.; Xu, Y.H.; Vo, T.D.; Lynch, B.S. Lipid-soluble green tea extract: Genotoxicity and subchronic toxicity studies. Regul. Toxicol. Pharm. 2017, 86, 366-373. [CrossRef] [PubMed]

223. Sur, T.K.; Chatterjee, S.; Hazra, A.K.; Pradhan, R.; Chowdhury, S. Acute and sub-chronic oral toxicity study of black tea in rodents. Indian J. Pharmacol. 2015, 47, 167-172. [PubMed]

224. Dostal, A.M.; Samavat, H.; Bedell, S.; Torkelson, C.; Wang, R.W.; Swenson, K.; Le, C.; Wu, A.H.; Ursin, G.; Yuan, J.M.; et al. The safety of green tea extract supplementation in postmenopausal women at risk for breast cancer: Results of the Minnesota Green Tea Trial. Food Chem. Toxicol. 2015, 83, 26-35. [CrossRef] [PubMed]

225. Dabanovic, V.; Soskic, M.; Durovic, D.; Mugosa, B. Investigation of heavy metals content in selected tea brands marketed in podgorica, montenegro. Int. J. Pharm. Sci. Res. 2016, 7, 4798-4804.

226. Peng, C.Y.; Zhu, X.H.; Hou, R.Y.; Ge, G.F.; Hua, R.M.; Wan, X.C.; Cai, H.M. Aluminum and heavy metal accumulation in tea leaves: An interplay of environmental and plant factors and an assessment of exposure risks to consumers. J. Food Sci. 2018, 83, 1165-1172. [CrossRef] [PubMed]

227. Yang, Y.; Liu, Y.; Huang, C.F.; de Silva, J.; Zhao, F.J. Aluminium alleviates fluoride toxicity in tea (Camellia sinensis). Plant Soil 2016, 402, 179-190. [CrossRef]

228. Li, H.S.; Huang, C.Q.; Jiang, Q.T.; Zhong, Y.Y.; Zhu, X.Y.; Chen, X.M.; Mo, W.M. Determination of five neonicotinoid pesticide residues in tea by online clean-up-liquid chromatouraphy-tandem mass spectrometry. Chin. J. Chromatogr. 2016, 34, 263-269. [CrossRef]

229. Yadav, S.; Rai, S.; Srivastava, A.K.; Panchal, S.; Patel, D.; Sharma, V.; Jain, S.; Srivastava, L. Determination of pesticide and phthalate residues in tea by QuEChERS method and their fate in processing. Environ. Sci. Pollut. R 2017, 24, 3074-3083. [CrossRef] 
230. Chen, H.P.; Pan, M.L.; Liu, X.; Lu, C.Y. Evaluation of transfer rates of multiple pesticides from green tea into infusion using water as pressurized liquid extraction solvent and ultra-performance liquid chromatography tandem mass spectrometry. Food Chem. 2017, 216, 1-9. [CrossRef]

231. Cho, S.K.; Abd El-Aty, A.M.; Rahman, M.M.; Choi, J.H.; Shim, J.H. Simultaneous multi-determination and transfer of eight pesticide residues from green tea leaves to infusion using gas chromatography. Food Chem. 2014, 165, 532-539. [CrossRef] [PubMed]

232. Witczak, A.; Abdel-Gawad, H.; Zalesak, M.; Pohorylo, A. Tracking residual organochlorine pesticides (OCPs) in green, herbal, and black tea leaves and infusions of commercially available tea products marketed in Poland. Food Addit. Contam. A 2018, 35, 479-486. [CrossRef] [PubMed]

233. Chen, H.P.; Hao, Z.X.; Wang, Q.H.; Jiang, Y.; Pan, R.; Wang, C.; Liu, X.; Lu, C.Y. Occurrence and risk assessment of organophosphorus pesticide residues in Chinese tea. Hum. Ecol. Risk Assess. 2016, 22, 28-38. [CrossRef]

234. Jayabalan, R.; Malbasa, R.V.; Loncar, E.S.; Vitas, J.S.; Sathishkumar, M. A review on kombucha TeaMicrobiology, composition, fermentation, beneficial effects, toxicity, and tea fungus. Compr. Rev. Food Sci. Food Saf. 2014, 13, 538-550. [CrossRef]

235. Li, Q.; Chai, S.; Li, Y.D.; Huang, J.A.; Luo, Y.; Xiao, L.Z.; Liu, Z.H. Biochemical components associated with microbial community shift during the pile-fermentation of primary dark tea. Front. Microbiol. 2018, 9, 1509. [CrossRef]

236. Hu, J.; Webster, D.; Cao, J.; Shao, A. The safety of green tea and green tea extract consumption in adults-Results of a systematic review. Regul. Toxicol. Pharm. 2018, 95, 412-433. [CrossRef]

237. Maeda-Yamamoto, M.; Nishimura, M.; Kitaichi, N.; Nesumi, A.; Monobe, M.; Nomura, S.; Horie, Y.; Tachibana, H.; Nishihira, J. A randomized, placebo-controlled study on the safety and efficacy of daily ingestion of green tea (Camellia sinensis L.) cv. "Yabukita" and "Sunrouge" on eyestrain and blood pressure in healthy adults. Nutrients 2018, 10, 569. [CrossRef]

238. Kasai, N.; Nakatsubo, G. Size-exclusion chromatography of tea tannins and intercepting potentials of peptides for the inhibition of trypsin-caseinolytic activity by tea tannins. J. Agric. Food Chem. 2006, 54, 5149-5156. [CrossRef]

239. Kondo, M.; Hirano, Y.; Ikai, N.; Kita, K.; Jayanegara, A.; Yokota, H. Assessment of anti-nutritive activity of tannins in tea by-products based on in vitro rumen fermentation. Asian Australas. J. Anim. Sci. 2014, 27, 1571-1576. [CrossRef]

240. Zheng, Q.M.; Han, C.Y.; Zhong, Y.M.; Wen, R.S.; Zhong, M. Effects of dietary supplementation with green tea waste on growth, digestive enzyme and lipid metabolism of juvenile hybrid tilapia, Oreochromis niloticus $\mathrm{x}$ O-aureus. Fish Physio. Biochem. 2017, 43, 361-371. [CrossRef]

241. Tan, Y.Q.; Chang, S.K.C. Digestive enzyme inhibition activity of the phenolic substances in selected fruits, vegetables and tea as compared to black legumes. J. Funct. Foods 2017, 38, 644-655. [CrossRef]

242. Liu, C.; He, W.J.; Chen, S.S.; Chen, J.; Zeng, M.M.; Qin, F.; He, Z.Y. Interactions of digestive enzymes and milk proteins with tea catechins at gastric and intestinal pH. Int. J. Food Sci. Technol. 2017, 52, 247-257. [CrossRef]

243. Fan, F.S. Iron deficiency anemia due to excessive green tea drinking. Clin. Case Rep. 2016, 4, $1053-1056$. [CrossRef] [PubMed]

244. Besral, B.; Meilianingsih, L.; Sahar, J. The effect of drinking tea to the anemia among elderly in bandung. Makara J. Heal. Res. 2007, 11, 38-43. [CrossRef]

245. Marouani, N.; Chahed, A.; Hedhili, A.; Hamdaoui, M.H. Both aluminum and polyphenols in green tea decoction (Camellia sinensis) affect iron status and hematological parameters in rats. Eur. J. Nutr. 2007, 46, 453-459. [CrossRef] [PubMed]

246. Ruenwongsa, P.; Pattanavibag, S. Imparement of acetylcholine synthesis in thianmine-deficent rats developed by prolonged tea consumption. Life Sci. 1984, 34, 365-370. [CrossRef]

247. Mohanpuria, P.; Kumar, V.; Yadav, S.K. Tea caffeine: Metabolism, functions, and reduction strategies. Food Sci. Biotechnol. 2010, 19, 275-287. [CrossRef]

(C) 2019 by the authors. Licensee MDPI, Basel, Switzerland. This article is an open access article distributed under the terms and conditions of the Creative Commons Attribution (CC BY) license (http://creativecommons.org/licenses/by/4.0/). 